\title{
The Landscape of Circulating Tumor Cell Research in the Context of Epithelial-Mesenchymal Transition
}

\author{
Aleksandra Markiewicz Anna J. Żaczek \\ Department of Medical Biotechnology, Medical University of Gdansk, Gdansk, Poland
}

\section{Keywords}

Circulating tumor cells - Epithelial-mesenchymal transition, associated phenotypes - Metastasis · Dissemination ·

Prognostic markers · Predictive markers

\begin{abstract}
The metastatic spread of cancer accounts for the vast majority of cancer-related deaths. It is mediated by tumor cells circulating in blood (called circulating tumor cells, CTCs), which escaped from their established niches. CTCs give a unique opportunity to look into the metastatic cascade and to study the molecular processes supporting the spread of tumor cells throughout the body. As current therapies are not sufficiently effective in treating metastatic disease, it is important to determine cellular and molecular features of cancer cells that "seed" new tumors in distant organs at early stages. In this review we focus on the role of the epithelial-mesenchymal transition program in providing a survival advantage to metastasizing tumor cells, especially CTCs, and put it in the context of clinical findings.

(c) 2017 S. Karger AG, Basel
\end{abstract}

\section{Introduction}

The presence of cancer cells in blood corresponds to one of the first steps of the metastatic cascade, which is a complex, multistep process that requires cancer cells to detach from the primary tumor, migrate through adjacent tissue, access and travel through the vasculature (as circulating tumor cells, CTCs), and then survive and proliferate in distant organs [1]. In some cancer cells, which arise from polarized and nonmotile epithelial cells, a migratory phenotype develops under the influence of various stroma-derived cytokines leading to reactivation of the embryonic program of epithelial-mesenchymal transition (EMT) $[2,3]$. During the traverse from the primary tumor to distant sites, cancer cells leave a supportive niche, which they have shaped for many years of tumor development, and enter a hostile milieu. Numerous data from in vitro and in vivo studies indicate that EMT is switched on in metastasizing cancer cells as it allows them to overcome limitations imposed by the environment. In this review we would like to summarize the current knowledge from basic and clinical studies regarding the role of epithelial and mesenchymal phenotypes of cancer cells, especially CTCs, in cancer progression.

\footnotetext{
Anna J. Żaczek

Department of Medical Biotechnology, Medical University of Gdansk Debinki 1

PL-80-211 Gdansk (Poland)

E-Mail azaczek@gumed.edu.pl
} 


\section{Role of EMT in CTC Biology}

CTCs have been considered the direct mediators of metastasis, and their detection in a number of solid tumors correlates with poor prognosis [4-13]. They were found more frequently in patients with metastatic cancer than in early setting [14]. But only recently has the evidence for their metastatic potential been found in in vivo studies. Metastasis-initiating cells capable of forming metastasis to bone, lung and liver metastases in mouse xenografts were found among CTCs isolated from breast cancer $(\mathrm{BC})$ patients $[15,16]$, confirming the hypothesis that CTCs are the real seeds of metastasis according to Paget's seed and soil theory [17]. The number of EpCAM+CD44+CD47+MET+ CTCs correlated with lower overall survival (OS) and increased number of metastatic sites [15]. Another study identified EpCAM-negative CTCs as capable of generating brain and lung metastases when xenografted in nude mice [16]. A potential signature of brain metastasis comprising "brain metastasis selected markers" HER2+/EGFR+/HPSE+/Notch1+ was identified in those EpCAM-negative CTCs [16].

Interestingly, in the study of Mego et al. [18] it was already noted that in metastatic $\mathrm{BC}(\mathrm{MBC})$ patients with undetectable epithelial CTCs (using CellSearch ${ }^{\circledR}$ ) aggressive cancer subtypes and brain metastases are more frequent. Further studies showed that mesenchymal CTCs are detected in $41 \%$ of MBC patients, especially in patients with triple negative or HER2+ tumors, where mesenchymal CTCs are the major subpopulation of CTCs [19]. Patients whose CTCs expressed EMT markers had a worse prognosis than patients with fully epithelial CTCs or no CTCs $[4,20]$. Therefore, clinical data point to asymmetry in frequency and malignancy of epithelial/mesenchymal phenotypes of CTCs, which has meaningful clinical implications.

EMT is an evolutionary conserved developmental program, which might be induced during cancer progression and contribute to metastatic spread [2,3]. It is described that EMT endows cancer cells with metastatic properties by enhancing mobility, invasion, and resistance to apoptotic stimuli $[2,21]$. Furthermore, EMT-derived tumor cells might acquire stem cell properties and exhibit therapeutic drug resistance [22]. Thus, the EMT program has emerged as a central driver of tumor malignancy, and its implications for CTC biology are under intensive investigation. Transitions between epithelial and mesenchymal phenotypes, and its reverse mesenchymal-epithelial transition (MET) are believed to be hallmarks of cellular plasticity allowing cancer cells a more efficient metastasis

Circulating Tumor Cell Research and Epithelial-Mesenchymal Transition
$[23,24]$. According to this model, metastasis often begins when primary tumor cells undergo EMT, i.e. they lose adhesion with neighboring cells partially or completely and gain migratory and invasive traits, eventually entering the bloodstream as CTCs $[1,3]$. Upon reaching a distant organ, these CTCs exit the bloodstream and undergo MET which is crucial for establishing a fully grown metastasis as it restores the high proliferative phenotype to cancer cells. Such a model would most probably hold true for hematogenous dissemination from the primary tumor, where cancer cells need to sequentially acquire invasive and proliferative features, but might be dispensable when metastasis takes place via another route. Metastasis via the lymphatic vasculature, which lacks a basal membrane, is devoid of pericytes, and where positive interstitial pressure is present [25], minimizes the need of tumor cells to migrate as they might be passively carried towards lymph nodes with the draining lymphatic fluid [26-28]. Thus, activation of EMT in one compartment might not provide the same advantage as in another. In experimental metastasis, where tumor cells are injected into the circulation, invasive properties characteristic of the mesenchymal phenotype are also becoming less significant, which does not render the mesenchymal phenotype fully dispensable. It is to be determined to what extent genetic manipulation used to study the role of EMT in cancer progression interferes with the physiological role of EMT, as high levels of EMT transcription factors, TWIST1/2, SNAIL, and SLUG, might downregulate crucial oncogenic switches as p53 or Rb [29-34]. Importantly, gene dosage-dependent function of TWIST1 was observed [35], which further underlines the complexity of the process. Thus, by artificially inducing EMT transcription factors (EMT-TF) physiological transition between EMT and MET states can be affected. It can be of a great importance, as epithelial and mesenchymal features are not mutually exclusive and coexpression of markers characteristic of both states might characterize a highly plastic cell phenotype. Such a state (called epithelial-mesenchymal plasticity) could, to some extent, endow cells with certain positive metastatic features present in epithelial and mesenchymal phenotypes alone (like increased resistance to anoikis provided by the mesenchymal state and proliferative features, which are the attributes of the epithelial state) [36]. Due to the transient phenotype of such states, it is envisioned that those plastic cells might not be easily identified but could significantly contribute to metastatic outgrowth [36]. Thus, tumor cells with a fully mesenchymal phenotype (post-EMT) might represent a quiescent fraction of cancer stem cells, which requires

Pathobiology 2017;84:264-283

DOI: $10.1159 / 000477812$ 
additional stimuli to initiate growth of distant epithelial metastases, whereas cells in an intermediate state, coexpressing epithelial and mesenchymal markers, would represent proliferating progenitor cells, able to more rapidly initiate distant colonization [37], similarly to cancer stem cells, which despite being rare are able to successfully maintain growth of an organ through life.

However, until now there has been no standard method or biomarker to define the EMT state of cells, which can lead to discordant interstudy results, when different markers are used. Cytokeratins (CKs) and vimentin are the most frequently used markers for epithelial and mesenchymal phenotypes, respectively. In addition, N-cadherin, TWIST1, SNAIL, SLUG, ZEB1, FOXC2, AKT2, $\mathrm{PI} 3 \mathrm{Ka}$, and fibronectin were also adopted as mesenchymal markers by a few investigators, while EpCAM (epithelial cellular adhesion molecule) and E-cadherin remained the main representatives for epithelial markers (Table 1). Cell surface vimentin was found to be a highly specific marker, expressed only on cancer cells [38]. The mechanism by which vimentin is being transported to the cell surface is not fully understood. It was shown that the process is positively regulated by phosphorylation - inhibition of cellular phosphatases results in increased presentation of vimentin on the surface of cancer cells, but not normal leukocytes [39]. It is possible that vimentin structural and functional changes caused by phosphorylation [40] result in its shift to the cell surface. In a microfluidics-based PCR system, expression profiles characteristic of mesenchymal cancer cells were identified (including IGF1, IGF2, EGFR, FOXP3, and TGFB3) in blood samples of prostate cancer patients [41]. Recently, plastin-3, a specific, novel marker useful for the detection of CTCs undergoing EMT, has been described [42, 43]. Also, although with a slight difference, some investigators used a ratio of epithelial and mesenchymal markers to describe CTC phenotypes $[19,44]$.

\section{Cluster Formation for Efficient Metastasis}

In cancers of different origins, studies in animal models and clinical samples have shown that CTCs can be detected as single cells or clusters containing two or more CTCs (also called circulating tumor microemboli) [14, 19, 45-48]. The frequency of such events estimated from mouse models showed that single CTCs dominate (97.4\%) over CTC clusters (2.6\%), but CTC clusters have higher metastatic potential $[49,50]$. Recently CTC clusters have been shown to be 23-50 times more competent to seed metastases than single cells [45]. Clustered CTCs are most likely directly derived from the primary tumors, rather than the proliferation of single CTCs or the aggregation of circulating CTCs [45]. Deep sequencing analysis of prostate cancer cells revealed evidence for frequent polyclonal seeding from the primary tumor to different secondary sites [51], which might suggest direct seeding by multicellular CTC clusters. These clinical data are also supported by in vivo studies using multicolor lineagetracing technology in mouse models showing that polyclonal metastases may be seeded by tumor cell clusters $[45,52,53]$. Importantly, clusters exhibit superior survival and colony-forming potential in culture [45], in vivo $[45,52,53]$ and probably in the clinical setting [54]. Within cell clusters from small cell lung cancer patients subpopulations of apoptotic cells were not detected, which might implicate protection from anoikis [54].

The biological basis of metastatic seeding by CTC clusters needs to be addressed to answer questions regarding their composition and role in the metastatic cascade, their interactions with stromal cells and eventually therapeutic implications. Currently it is known that CTC clusters may retain the expression of epithelial cytoskeletal and adhesion genes such as cytokeratin-14, E-cadherin, Pcadherin [53], or plakoglobin [45], but also strong expression of mesenchymal markers such as FN1 (fibronectin 1), $\mathrm{CDH} 2$ (N-cadherin), and SERPINE1/PAI1 (serpin peptidase inhibitor, clade E), FOXC1 (FN1 forkhead box protein C1) observed within the clusters [19]. The dynamics of epithelial-mesenchymal differentiation within the clusters is unknown. It has been postulated that mesenchymal transformation of epithelial cells mediated by TGF- $\beta$ released from platelets may take place within the clusters [45], but the issue warrants further studies.

\section{Staying Mesenchymal - Cooperation with Other Cells}

The EMT process is induced in cancer cells by multiple cell types present in the tumor, like fibroblasts, mesenchymal stem cells, monocytes, or macrophages (reviewed in Ye and Weinberg [23]). Continuous secretion of EMT triggering signals allows for sustaining mesenchymal features in migrating cancer cells [55]. Even though EMT induction is being linked with hypoxia, an increased percentage of cancer cells with EMT phenotype can also be observed in vascularized areas of basal-like BC, what might represent the ability of endothelial cells to trigger EMT by secreting hepatocyte growth factor [56]. Thus, 


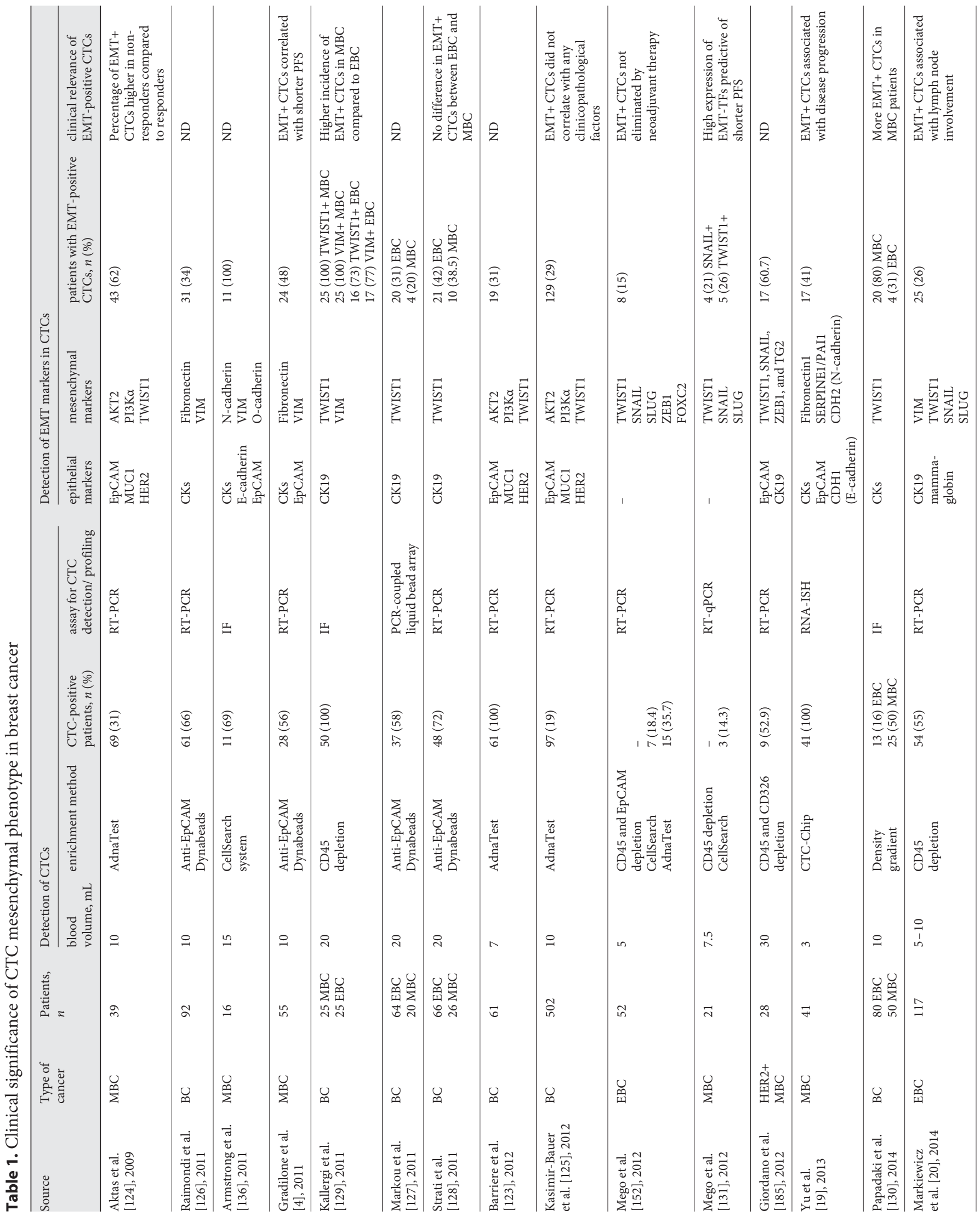




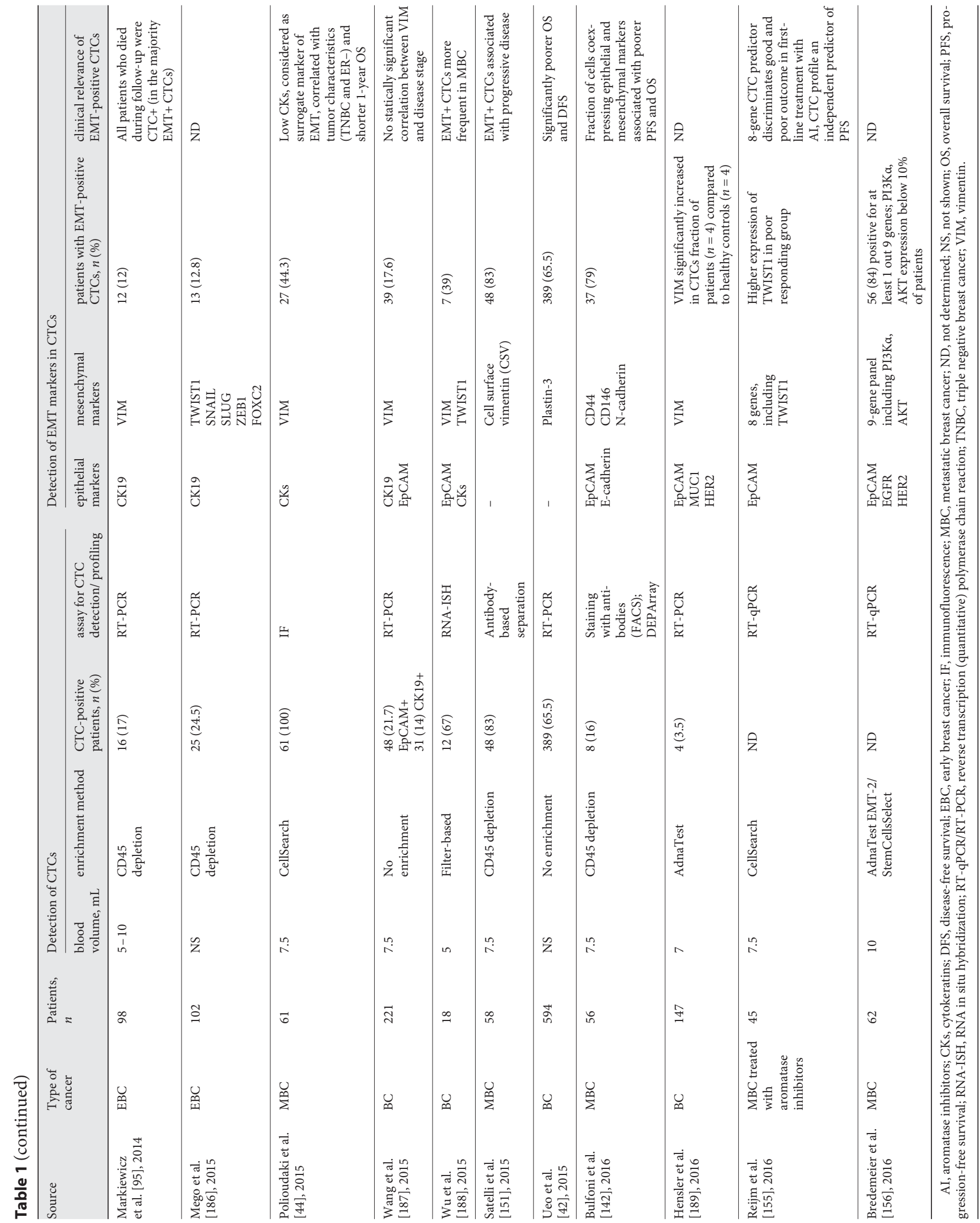


endothelial cells of primary tumor vasculature would also count as stimulators of EMT in intravasating tumor cells. The underlying molecular mechanisms by which cancer cells outside of the primary tumor, like CTCs, maintain the EMT state have not been fully elucidated. Theories explaining the mesenchymal status of CTCs concern the role of interactions either with blood cells or with cancer cells within the clusters [57]. Platelets seem to be of special importance for metastasis, since thrombocytosis is frequently observed in patients with metastatic cancers [58]. Platelets facilitate invasion of cancer cells, intra- and extravasation of CTCs (by secreting lysophosphatidic acid) [59,60], protect them from various host attacks, such as immune assaults $[61,62]$, apoptosis $[63,64]$ and shear stress $[57$, $65,66]$. Importantly, platelets may also contribute to EMT of CTCs and more efficient metastases formation [67]. Recently, mesenchymal CTCs isolated from BC patients were found clustered with platelets, and gene expression profiling of these CTCs was enriched in the TGF- $\beta$ signaling pathway [19]. CTCs themselves can trigger so-called tumor cell-induced platelet aggregation, which activates platelets and leads to their attachment to the surface of CTCs by a GPIIb-IIIa-fibrinogen bridge and upregulated P-selectin. Tumor cell-induced platelet aggregation promotes platelets to release $\alpha$-granules, which contain high levels of TGF- $\beta$ and platelet-derived growth factor, both considered to be powerful activators of EMT [57]. Platelet-derived TGF- $\beta$ and direct platelet-tumor cell contacts synergistically activate the TGF- $\beta /$ SMAD and NF- $\mathrm{KB}$ pathways in cancer cells, resulting in their transition to an invasive mesenchymal-like phenotype and enhanced metastasis in vivo [67]. It requires further studies to clearly show whether platelets can induce EMT in epithelial cancer cells present in circulation or whether they merely sustain the mesenchymal phenotype which intravasating tumor cells had acquired in the primary tumor. It is possible that during their short transition in circulation (estimated CTC half-life 1-2.5 h [68]), CTCs maintain the phenotype with which they entered the blood stream, and only at the distant site can changes in EMT status be observed. Beerling et al. [69] showed that the percentage of E-cadherin low tumor cells is the same (60\%) in circulation and in single cells which disseminated to the lungs $(60 \%)$, but drops to $20 \%$ at the stage of 2 -cell clusters and further to $0 \%$ at the stage of 3 -cell clusters in the lungs. This progressive decrease in mesenchymal features at a distant site could represent the time frame required for mesenchymal cancer cells to revert back to the epithelial state in the absence of strong EMT cues present in the primary tumor or in the circulation.

Circulating Tumor Cell Research and Epithelial-Mesenchymal Transition
A unique example of cells which are able to provide EMT triggering signals, mostly TGF- $\beta[19,70,71]$ during the whole metastatic cascade, within and outside of the primary tumor, are cancer-associated fibroblasts (CAFs). CAFs are not only part of the primary tumor niche, as CTCs were observed in heterotypic clusters with CAFs $[46,72]$. In the original study of Duda et al. performed on mice carrying Lewis lung carcinoma, cancer cells were shown to be shed from the primary tumor together with CAFs, what decreased their apoptosis rate and facilitated formation of lung metastases [72]. In the same study CAFs were also identified in metastases to the brain (which does not contain fibroblasts) of lung, breast, kidney, and endometrial cancer patients, indicating relevance of this mechanism in various cancers [72].

\section{EMT in Dissemination}

In animal models it has been shown that EMT-induced cancer cells disseminate even at the very early stages, preceding detection of invasive tumor $[73,74]$. To investigate early tumor cell dissemination in vivo, Hüsemann et al. [74] used the MMTV-Her2 mouse mammary tumor model and found increased Twistl expression in hyperplastic lesions during primary tumor development. Concomitantly, these mice presented increased disseminated cancer cells in bone marrow at this stage, suggesting that EMT may be involved in CTC/disseminated cancer cell seeding. Consistently with these findings, in a K-rasdriven mouse pancreatic tumor model, pancreatic CTCs were detected at the premalignant stage of tumor progression [73]. The majority of these CTCs presented a mesenchymal phenotype and expressed ZEB2, indicating activation of the EMT program [73].

Not accounting for the tumor stage development, but still showing the role of EMT activation in increased CTC seeding is the study of Tsai et al. [75], who examined the number of CTCs in a mouse model of squamous cell skin carcinoma in response to TWIST1 induction. TWIST1 expression dramatically increased the number of CTCs compared with control mice, and these CTCs presented an EMT phenotype with loss of E-cadherin and expression of vimentin [75]. Similarly, in the MDA-MB-468 breast tumor xenograft model, expression of SNAIL and SLUG increased the presence of vimentin-positive CTCs [76], and in a 4T1 mouse model of BC, ectopic expression of miR-200, which inhibits EMT, reduced the number of CTCs seeded from the primary tumors, but resulted in a higher metastatic tumor burden upon intravenous injec-

Pathobiology 2017;84:264-283

DOI: $10.1159 / 000477812$ 
tion [77]. Quantification of this niche-dependent advantage of an individual epithelial/mesenchymal phenotype was performed in an orthotopic MMTV-PyMT-driven mouse model of $\mathrm{BC}$, which showed that the ratio of epithelial to mesenchymal cancer cells is 100:1 in primary tumor, 15:1 in blood and 150:1 in lung metastases, presenting an advantage of the mesenchymal phenotype in circulation [22]. In another study of the MMTV-PyMTdriven BC mouse model [69], the disproportion between epithelial and mesenchymal CTCs was not so significant, however much more widespread. Epithelial CTCs constituted from 0 to $80 \%$ (average $40 \%$ ) of CTCs detected. Despite this difference, both studies show enrichment of the mesenchymal phenotype of cancer cells in circulation. While trying to translate this discovery to the clinical situation, we have to keep in mind that MMTV-PyMT-driven BCs create tumors of the luminal subtype [78], thus not fully recapitulating the heterogeneity of subtypes seen in $\mathrm{BC}$ patients, which show differences in the percentage of the epithelial/mesenchymal phenotype of CTCs depending on the tumor subtype [19].

Despite the large amount of data supporting the role of EMT in tumor progression, experimental data do not show a uniform picture regarding metastatic competence of the epithelial and mesenchymal phenotype. Pioneering work of Tsui et al. [79] presented that tail vain, but not subcutaneous, injection of epithelial cancer cells is sufficient for the establishment of lung metastases, suggesting inability of epithelial cells to intravasate. On the other hand, neither subcutaneous nor tail vain injection of mesenchymal cells resulted in formation of lung metastases (despite the presence of mesenchymal CTCs in the circulation), which indicated inefficient colonization by mesenchymal cells. Only subcutaneous injection of a mixture of epithelial and mesenchymal cancer cells resulted in formation of lung metastases, which indicates cooperation between the two types of cells during the intravasation process [79]. In in vitro tests and in vivo mouse models, prostate cancer cells of the mesenchymal phenotype were also shown to increase the metastatic capacity of normally poorly motile, but proliferative epithelial cancer cells [80]. This cooperative model has recently been challenged, as Ras-transformed human mammary cells of mesenchymal phenotype, when implanted to mammary fat pads of NOD/SCID mice were shown to seed lung metastases as opposed to their epithelial counterparts [101]. In other models, inhibition of EMT did not influence the rate of lung metastases [22] or was similar between epithelial and mesenchymal phenotypes [69]. Trying to draw conclusions from these studies, we need to remember that model-dependent factors might account for the observed differences, as multiple factors - way of tumor cell injection (tail vain vs. mammary fat pad), presence of the immune system, cancer subtype and its inherent malignancy, marker used for defining EMT status as well as the ability of cancer cells to transit between the epithelial/ mesenchymal state - can influence the results.

\section{EMT and Stemness}

In classical definition, stem cells (SCs) are self-renewing cells, which through life are able to recapitulate heterogeneity of the cell population in an organ in which they reside [81]; often they are also considered to be slowdividing cells [82-86]. By analogy, cancer stem cells (CSCs) would be able to indefinitely recreate heterogeneity of the primary tumor $[87,88]$. In cancer, numerous markers have been described to be expressed on cells with SC properties - to name the few most common in solid tumors: ALDH1, CD133, CD90, $\alpha_{6}$-integrin, members of the $\mathrm{ABC}$ transporters, or combination of CD44/CD24 status [89]. Cancer cells of the mesenchymal phenotype were shown to be enriched in these stem cell markers [9092], and induction of EMT in mutant HRAS-transformed immortalized human mammary epithelial cells and basal $\mathrm{BC}$ cell lines resulted in the generation of cells with the SC phenotype (CD44+CD24-/low) from non-SC (CD44low$\mathrm{CD} 24+)$, enriched in tumorigenic properties in vivo [90, $91,93]$. Although the mechanism is not universal to all $\mathrm{BC}$ cell lines (inefficient generation of cancer SC-like cells in luminal BC cell lines [93]), it clearly points to plasticity of the CSC-like state, allowing for easy transit between SC and non-SC phenotype. However, individual CSC markers do not detect a single population of cells with enriched tumorigenic properties. Studies on clinical samples of $\mathrm{BC}$ revealed that ALDH1-expressing, proliferative cells are present in the tumor center and exhibit an epithelial phenotype, whereas CD44+/CD24-, quiescent cells are located at the tumor periphery and are mesenchymal [94]. Interestingly, both CSC phenotypes were highly plastic, able to interconvert between both epithelial and mesenchymal CSC states. As the rate of proliferation is one of the factors determining sensitivity of cancer cells to chemotherapy and ability to colonize a distant site, proliferative nonmigratory epithelial cells would be more sensitive to chemotherapy but more capable of establishing metastases. Following this reasoning, mesenchymal cells would represent a transitory CSC-like phenotype allowing cancer cells to disseminate from primary 
tumor and reach a distant site where a tumor growth is recapitulated by CSC-like cells which reverted back to epithelial state. Indeed, epithelial traits of metastases are often more pronounced than in the corresponding primary tumors [95-98]. Also our study in BC showed that loss of E-cadherin is observed in $37 \%$ of primary tumors but only in $2 \%$ of matched lymph node metastases [95]. Interestingly, albeit there is strong E-cadherin staining, metastases consistently showed a decreased rate of proliferation and increased expression of EMT transcription factors TWIST1, SNAIL, and SLUG in comparison to primary tumors. Expression of EMT transcription factors TWIST1 and/or SLUG correlated with cell division rate in primary tumors and lymph node metastases, with 50\% reduction in the Ki-67 labeling index in TWIST1 and/or SLUG+ samples, underlining the inhibitory effect of EMT-TF on cell division. Identification of E-cadherinpositive, EMT-TF-expressing cells could also point to the presence of cancer cells with partial EMT states. Along this line, Del Pozo et al. [99] showed in a BC mouse model that metastasis-initiating cells (MICs, CD24+/CD90+) presented more mesenchymal features (vimentin, TWIST1, SNAIL, SLUG, ZEB1 expression, E-cadherin downregulation); however, heterogeneity of EMT markers was observed, indicating frequent partial EMT states. Cells with partial EMT phenotype were characterized by increased tyrosine kinase receptor ALX expression. Additionally, MICs were able to activate fibroblasts more efficiently than non-MICs, and their gene expression signature was related to extracellular matrix remodeling (matrix metalloproteinases, collagen and fibronectin expression), supporting their role in metastatic niche preparation [99]. Moreover, MICs secreted CCL2, which attracts monocytes, recently shown to be supportive of metastasis growth at the very early stages of metastasis initiation [100].

In a mouse model of $\mathrm{BC}$, mesenchymal cancer cells when forced to revert to the epithelial state (MET) reduced the frequency of CSC phenotype (CD44+/CD24-), which was linked with increased sensitivity to a range of drugs: doxorubicin, paclitaxel, proteasome inhibitors and MAPK/EGFR inhibitors [101]. Also, in a BC model, upon treatment of mice with cyclophosphamide, cells which had undergone EMT were more resistant and abundant than epithelial cancer cells [22]; inhibition of EMT during concurrent chemotherapy administration resulted in reduced numbers of lung metastases [22]. This increased ability to sustain toxicity might be pertinent to cancer cells in the mesenchymal state, which were shown to have higher expression of multidrug resistance pump breast

Circulating Tumor Cell Research and Epithelial-Mesenchymal Transition cancer resistance protein and P-glycoprotein as well as DNA-repairing enzyme $O^{6}$-methylguanine-DNA methyltransferase, H2Afx, Xrcc6 [92]. In a study of MBC [4], a statistically significant correlation was found between the expression of multidrug resistance proteins and ALDH1 in CTCs, as well as a shorter progression-free survival (PFS) time for patients whose CTCs expressed two or more multidrug resistance proteins.

\section{EMT in Immune Escape}

Melanoma is considered to be one of the most immunogenic cancers, with multiple melanosome differentiation markers triggering the immune response, like tyrosinase [102, 103], TRP2 [104] or gp100 [105]. Thus, melanoma is frequently used in immuno-oncology research to study how tumor and its microenvironment are shaped by the immune system [106]. Such interactions can be studied in detail in animals with a functional immune system; thus, syngeneic mouse models are frequently used. In one of such studies [107] performed in a C57BL/6 mouse model injected with the melanoma cell line $\mathrm{HCmel}$, downregulation of a large panel of melanoma differentiation markers was observed in relapse tumors growing in the inflammatory tumor microenvironment. Interestingly, increased expression of proinflammatory cytokines (IL- $1 \beta$, TNF- $\alpha$, IL-6, IFN- $\gamma$ ), enhanced by infiltration of CD8+ T cells and CD11b+ myeloid cells, occurred concomitantly with decreased recognition of cancer cells by T cells. Spindle shape morphology and gene expression profiling of cancer cells suggested their mesenchymal-like phenotype [107]. Similarly, a decrease in melan A expression in various melanoma cells following TGF- $\beta$ incubation (and a switch to the mesenchymal phenotype) was linked to their decreased clearance by melan A recognizing CD8+ T cells in vitro [108]. In a syngeneic mouse $\mathrm{BC}$ model, wild-type $\mathrm{FVB} / \mathrm{N}$ mice injected with neu-expressing (mouse version of HER2) tumor cells with epithelial morphology gave rise to neu-negative tumors showing mesenchymal morphology, consistent with induction of the EMT phenotype $[92,109]$. In this model, CD4+ T cells were found to be primarily responsible for killing neu+ tumor cells, whereas CD8+ T cells were promoting EMT in cancer cells.

Tumors can evade the immune system not only by downregulation of highly immunogenic proteins, but also via reducing the exposure of their entire protein content (potential neoantigens) to immune cells. Lung cancer cells of mesenchymal phenotype show reduced

Pathobiology 2017;84:264-283

DOI: $10.1159 / 000477812$ 
expression of immunoproteosome subunits (PSMB8, PSMB9, PSMB10) specializing in processing peptides to be presented on the cell surface and express less than half of their proteins on HLA type I molecules than epithelial lung cancer cells do, which allows them a more successful evasion of the immune system [110].

Moreover, repertoire of EMT-linked immune escape strategies is not restricted to hiding from the immune system, but covers also direct inhibition of immune cells. PDL1 expression, which transmits a potent inhibitory signal to $\mathrm{T}$ cells, correlates with the EMT signature of BC (from microarray gene expression profiles) as well as loss of $\mathrm{E}$ cadherin and acquisition of vimentin expression in immunohistochemically analyzed BC sections [111]. TGF- $\beta$ treatment of basal/mesenchymal BC cell lines and primary luminal epithelial cells isolated from the breast can further upregulate PD-L1 expression on their surface [111]. Similarly, in primary tumors of colorectal cancer patients PD-L1 expression was found in cells with signs of EMT (E-cadherin downregulation or vimentin expression) [112]. Additionally, in vitro coculture of breast, lung, and liver cancer cell lines induced to undergo EMT with proinflammatory cytokines (TGF- $\beta$, IFN- $\gamma$, TNF- $\alpha$ ) resulted in activation of various, tumor type-specific immunomodulatory functions on different subpopulations of immune cells, like reduction in NK cells and T-cell proliferation or induction of regulatory $\mathrm{T}$ and $\mathrm{B}$ cells [113]. In a melanoma mouse model in vivo as well as in human melanoma cells in vitro, SNAIL+ cancer cells of the mesenchymal phenotype trigger immune suppression by inducing regulatory $\mathrm{T}$ cells and impaired dendritic cells [114].

Tumor cells themselves, but also EMT-promoting stimuli, may assist immune escape. TGF- $\beta$, a known inducer of EMT, can promote an immunosuppressive environment within the tumor by directly influencing cells of both innate and adaptive immunity. TGF- $\beta$ was shown to inhibit on multiple levels antigen-presenting cells, NK cells, and T cells as well as induce generation of regulatory T cells which support tumor growth $[115,116]$. Previously mentioned platelets, by coating CTCs, can create a physical barrier protecting CTCs with downregulated MHC class I molecules from NK cell attack [117] or transfer MHC class I molecules to cancer cells allowing molecular mimicry [118]. The role of platelets in metastasis was in detail reviewed in Lou et al. [57] and Leblanc and Peyruchaud [119].

Although signs of immune evasion were mostly found on post-EMT cancer cells, not only the mesenchymal phenotype allows to evade the immune system. Gene expression profiling of EpCAM+ CTCs from colorectal pa- tients showed increased (in comparison to primary tumor) expression of CD47, which acts as phagocytosis inhibitor [120]. And E-cadherin, as a ligand of inhibitory killer cell lectin-like receptor G1 (KLRG1) on NK cells, is able to suppress the function of NK cells by lowering their ability (via antibody-dependent cellular toxicity) to destroy HER2-overexpressing, trastuzumab-treated BC cells [121].

A graphical summary of the above described features of cancer cells linked to EMT and metastatic competence is presented in Figure 1.

\section{Clinical Significance of EMT in CTCs}

\section{Prognostic Significance}

Since the first report on CTCs in 1869 [122] numerous studies on the clinical significance of CTCs in different tumors have been published [5]. The prognostic value of CTC enumeration in BC [6-9], prostate [10], colorectal [11], and lung cancers [12], and many other cancers has been described. In MBC, CTCs count is a level-of-evidence 1 prognostic dynamic biomarker [13]. However, the actual utility of CTCs still remains largely academic. One of the reasons for the limited clinical use of CTCs is the inability to accurately distinguish highly aggressive from less aggressive cells. The characteristics of clinically relevant CTCs remain the key issue. EMT-associated changes of phenotype have been postulated to be responsible for the aggressiveness of CTCs.

To date, the majority of research studies reporting on the existence of EMT in CTCs has been performed in patients with BC (Table 1). Several groups have evaluated the expression of 3 EMT markers: AKT2, PI3Ka, and TWIST1; the studies have consistently found that about one third of BC patients have CTCs positive for at least 1 of these EMT markers [123-125]. In another study of BC patients, cells negative for CK/CD45 transcripts but positive for vimentin and fibronectin were detected in 34\% of the patients [126]. Another 2 groups reported TWIST1positive CTCs being detected in 31.2 and $38.5 \%$ of BC patients, respectively $[127,128]$. Yu et al. [19] using 7 pooled epithelial transcripts (cytokeratins 5, 7, 8, 18, and 19; EpCAM and E-cadherin) and 3 mesenchymal transcripts (fibronectin, N-cadherin, and SERPINE1/PAI1) found that mesenchymal features of CTCs in MBC patients varied according to $\mathrm{BC}$ subtype. In patients with triple negative or HER2+ tumors, mesenchymal CTCs were the major subpopulation of CTCs. Interestingly, the authors also reported that expression of the mesenchymal 


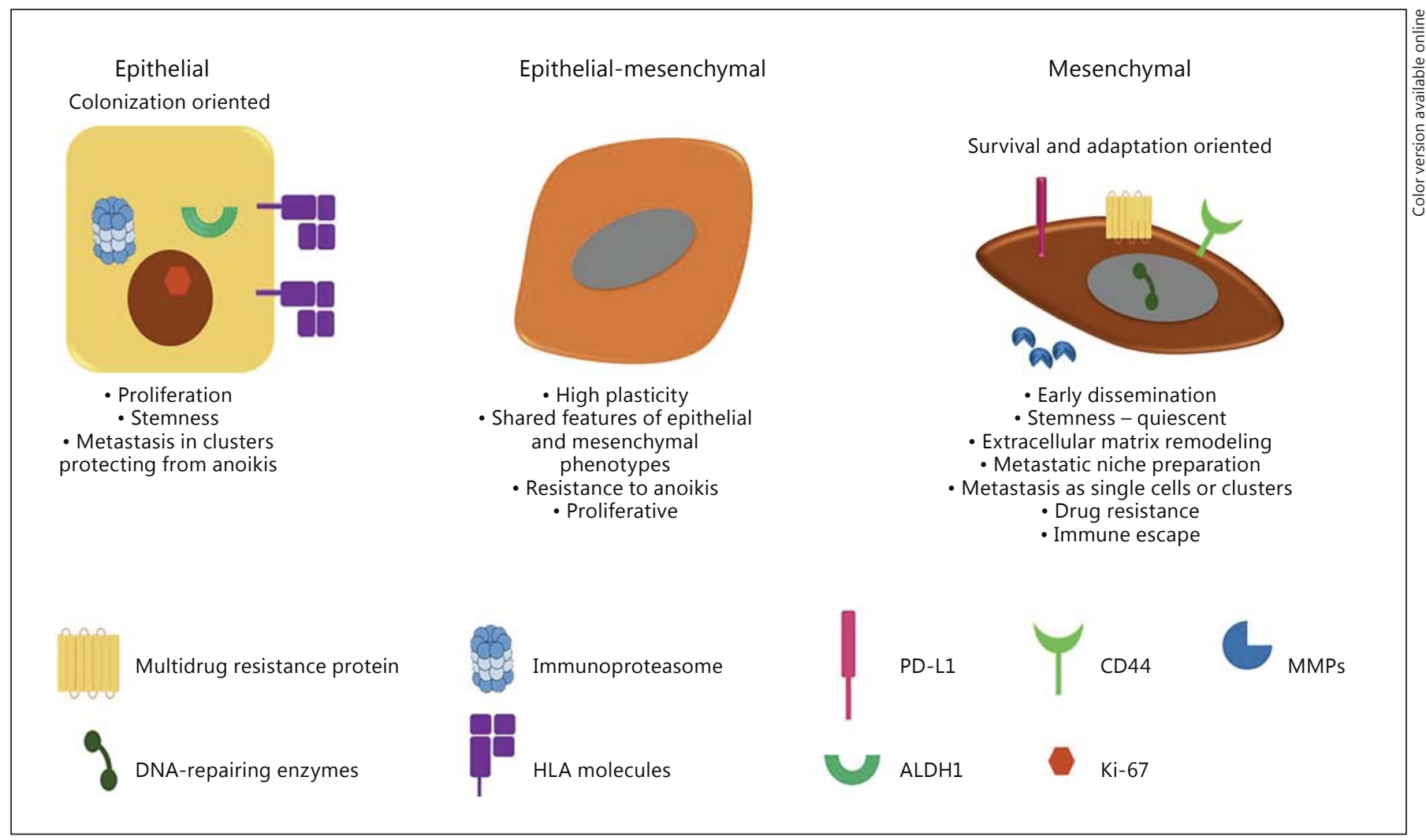

Fig. 1. EMT-induced changes in cancer cells. EMT can generate multiple phenotypes in cancer cells, linked not only to differences in expression of epithelial and mesenchymal markers, but also to polarity (apicobasal in epithelial cells and front-back polarity in mesenchymal cells), stemness, proliferative capabilities, as well as invasion and migration pattern (secretion of extracellular matrixdegrading metalloproteinases, MMPs, by mesenchymal cells). Whereas epithelial cells seem to be more capable of establishing tumor colonies at distant sites (proliferative phenotype - Ki-67+), mesenchymal cells are more resilient to changing conditions, thus are better equipped to survive during the metastatic cascade. Focusing on differences between cells with different EMT phenotypes, in mesenchymal cancer cells immunogenicity might be reduced due to a decrease in immunoproteasome levels, decrease in the number of HLA molecules presenting potentially antigenic protein on the cell surface or increased expression of immune cellinhibitory molecules such as PD-L1, allowing mesenchymal cancer cells for more efficient immune escape. EMT was also shown

markers was more likely to be associated with clusters of CTCs rather than a single set of migratory cells [19].

Presence of mesenchymal markers was higher in MBC patients than in early stage BC patients $[129,130]$ and was associated with lymph node involvement [20], suggesting that EMT phenotype is directly related to the metastatic potential of CTCs. However, plastin-3 expressed in CTCs

Circulating Tumor Cell Research and Epithelial-Mesenchymal Transition to induce different stemness features to cancer cells - ALDH1 characterizes a subpopulation of cells with stem cell characteristics, which are proliferative, whereas the CD44+/CD24- phenotype is characteristic of quiescent mesenchymal stem cells. Additionally, mesenchymal cancer cells seem to be more resistant to therapies due to presence of multidrug resistance proteins, protecting cells from accumulation of toxic compounds. Additionally, expression of proteins involved in the repair of damaged DNA can be observed in mesenchymal cancer cells. Between phenotypes on opposite sides of the EMT spectrum, a range of intermediate phenotypes can develop. These cells characterized as having expression of both epithelial and mesenchymal markers, share features of both phenotypes, like resistance to anoikis (mesenchymal feature) or proliferative phenotype (epithelial feature). Exact characteristics of such cells will be dependent on the extent of EMT activation. Cells with a mixed epithelial-mesenchymal phenotype are thought to be highly plastic, thus very responsive to changes in the environment. undergoing EMT was found with a similar frequency in all stages of BC, from I to IV [42].

Mesenchymal CTC detection correlated with poor patient outcome both in early [95] and metastatic BC [4]. Presence of mesenchymal CTCs was associated with shorter survival in MBC [4], which was also confirmed using a single CTC analysis approach [44]. MBC patients 
undergoing high-dose chemotherapy followed by autologous hematopoietic stem cell transplantation with high expression of EMT-TF had shorter PFS compared to patients with low expression [131]. Furthermore, in the study of 594 BC patients of all stages mesenchymal CTCs were shown to be an independent prognostic marker of OS and disease-free survival in multivariate analysis [42]. Also, in early BC detection of mesenchymal CTCs correlated with patients' deaths [95]. Importantly, mesenchymal CTCs allowed a more accurate prediction of prognosis than the expression of epithelial markers alone [4].

Clinical significance of mesenchymal CTCs was examined not only in BC, but also in other cancers, including colorectal [43, 132], hepatocellular [133, 134], gastric [135], prostate [41, 136], bladder [137], ovarian [138], endometrial [139], and non-small cell lung cancer [140]. The majority of data concern the metastatic setting. In general, similarly to $\mathrm{BC}$, mesenchymal CTCs seem to be associated with metastasis $[43,134]$ and poor patient outcome [43, 132]. Expression of EMT-related transcripts (PI3Ka, TWIST1 and AKT2) in CTCs from bladder cancer patients correlated with clinical stage and could be detected in patients negative for epithelial transcripts [137].

Currently, the focus is put on different states of EMT, with the emerging notion that partial EMT, but not necessarily a complete EMT, is associated with aggressive tumor progression. Armstrong et al. [136] examined the occurrence of EMT in CTCs from patients with progressive metastatic solid tumors, including castration-resistant prostate cancer and $\mathrm{MBC}$, and showed that the majority $(>80 \%)$ of CTCs coexpressed epithelial proteins along with mesenchymal proteins. CTCs from metastatic prostate cancer patients were found to exist in phenotypic states of epithelial-mesenchymal plasticity [141]. In patients with advanced non-small cell lung cancer, the majority of isolated or clustered CTCs harbor a dual epithelial/mesenchymal phenotype, and only some CTCs express exclusively vimentin or fibronectin [140]. Importantly, a fraction of cells coexpressing epithelial and mesenchymal markers was associated with poorer PFS and OS in MBC [142]. In lung cancer patients it was shown that radiotherapy can induce release of single CTCs or CTC clusters [143]. Comparative analysis of CTC numbers (as single cells or clusters) before and after irradiation showed an increase in CTC number (CK+/CD45-/ DAPI+) in $50 \%$ (low radiation group) to $77 \%$ (high radiation group) of the patients [143].

Overall, presence of CTC clusters was associated with a significantly worse clinical outcome as compared with the presence of single CTCs $[45,54,144]$. In BC, CTCs were identified in 54 out of 79 patients (68\%). Patients with detectable clustered CTCs had a significantly shorter PFS than with single CTCs [45]. Another prospective study confirmed the prognostic significance of CTC clusters in BC showing that the presence of CTC clusters was a strong independent predictor of PFS in advanced-stage BC patients, particularly in patients with inflammatory $\mathrm{BC}$ [144]. In prostate cancer, the presence of CTC clusters strongly correlated with a shorter OS [45]. Also in small cell lung cancer, presence of CTC clusters was an independent prognostic factor correlated with significantly shorter PFS and OS compared with the absence of CTC clusters [54].

\section{Predictive Significance}

Although increasing data and clinical trials show that CTCs can improve the prognostic accuracy, their predictive role is less extensively reported; particularly scarce are data concerning the predictive role of mesenchymal CTCs in this context.

The majority of reports on the possibility of monitoring therapeutic efficacy concern the enumeration of CTCs, based on EpCAM with the use of the CellSearch ${ }^{\circledR}$ system, which is the only system approved by the FDA up to date. When CTC detection in the context of neoadjuvant therapy is concerned, the GeparQuattro study (which is a large phase III trial, including the highest number of patients in this setting till now $[n=213]$ ) reported no correlation between the persistence of CTCs and the treatment response of tumors [145]. This result remains in agreement with many other reports summarized by Bidard et al. [9], showing that CTCs detected by CellSearch ${ }^{\circledR}$ did not correlate with the response to therapy, measured by the completion of a pathological complete response. In contrast, a study conducted on 91 nonmetastatic patients with the Maintrack $^{\circledR}$ cytology-based CTC detection system reported that different patterns of CTC decrease during adjuvant therapy were associated with complete response [146]. Studies conducted in the adjuvant setting reported a significant prognostic impact of CTC detection (with the CellSearch ${ }^{\circledR}$ technique). In the German multicenter SUCCESS study of more than 2,000 patients eligible for adjuvant chemotherapy, CTC positivity before chemotherapy was confirmed as an independent prognostic marker for disease-free survival and OS [7]. CTC positivity after chemotherapy had a marginally significant prognostic impact on survival. A single-center study conducted at the M.D. Anderson Cancer Center also reported that detection of CTCs predicted early recurrence and decreased OS in 304 chemonaïve patients with non-MBC [147]. A pooled anal- 
ysis including studies in adjuvant and neoadjuvant settings reported CTCs (detected using CellSearch ${ }^{\circledR}$ ) as an independent prognostic factor [8]. In metastatic disease the persistence of CTCs after treatment has been systematically shown to predict lack of responses to therapy [148150]. CTC count superiority over serum tumor markers (CEA, CA15.3) was demonstrated in a pooled analysis of 1,944 patients. CTC count was associated with performance status, number of metastatic sites, elevated lactate dehydrogenase, elevated serum tumor markers, PFS, and OS. Moreover, adding CTC count and its change during therapy to an optimized clinicopathological model significantly increased the prognostic value of the model [9]. It was postulated that CTC count monitoring during therapy would allow early detection of resistance to therapy and ultimately improve the management of $\mathrm{MBC}$ patients.

The data concerning the predictive role of mesenchymal CTCs are very limited. No prospective clinical trials regarding the role of different phenotypes of CTCs were reported. Presence of mesenchymal CTCs was associated with progressive disease in both colon cancer and $\mathrm{BC}$ patients undergoing postsurgery adjuvant chemotherapy [38, 151]. MBC patients not responding to therapy showed increased levels of EMT markers compared to responders [124]. Moreover, primary BC patients treated with neoadjuvant therapy presented overexpression of EMT-inducing TF gene transcripts in their CTC fractions more frequently. As the number of complete responses in this subgroup was also lower, the authors concluded that neoadjuvant treatment was not able to eliminate CTCs with EMT phenotype [152].

Importantly, CTC phenotype changes during the course of treatment may serve as pharmacodynamic monitoring tools. In MBC patients not responding to treatment, the number of mesenchymal CTCs increased, while responders presented a decrease in CTC number and/or a proportional decrease in mesenchymal (compared to epithelial) CTCs [19]. These findings remain in agreement with studies highlighting the importance of EMT in conferring chemoresistance in BC and pancreatic cancer models $[22,153]$. Recently, short-term expansion of CTCs in microwell-based culture was reported to predict response to anticancer therapy in early-stage, locally advanced and MBC [154]. Cluster formation in cell culture was affected by the presence and duration of systemic therapy, and its persistence may reflect therapeutic resistance as it correlated with shorter OS [154]. Also gene expression profiles in CTCs were reported to predict response to therapy with aromatase inhibitors [155] and during the course of palliative treatment in MBC [156].

Circulating Tumor Cell Research and Epithelial-Mesenchymal Transition
In some cases estrogen receptor- $\alpha$ (ER) expression was shown to be downregulated in CTCs of BC patients, in comparison to their ER+ primary tumor $[157,158]$. Heterogeneous or lack of expression of ER in CTCs of patients with ER+ primary tumor was linked with resistance to fulvestrant of BC patients [159]. Interestingly, downregulation of ER is associated with acquiring a mesenchymal phenotype of BC cells due to EMT [160-162]. One of the ER isoforms, ERa36, which might be expressed in ERnegative BC (lacking the classical ERa isoform of $66 \mathrm{kDa}$ molecular mass) [163] was identified as being linked with the EMT phenotype of BC cells [164]. Also overexpression of HER2 in BC can result in a higher tumor burden, with cancer cells showing the EMT phenotype [165]. In a view of the EMT role in cancer, downregulation of ER and overexpression of HER2 can thus have a far more profound influence on the disease progression than just responsiveness to targeted therapy. Detailed studies are warranted to uncover the biological and clinical consequences of ER and HER2 expression in CTCs.

\section{Targeting CTCs}

Targeting Unique Cancer Markers

There are several ongoing large prospective interventional studies in which therapeutic decisions are based on CTC presence and/or CTC phenotypes in both non-MBC and MBC. The first prospectively randomized clinical trial that evaluated the clinical utility of CTCs was conducted by the SouthWest Oncology Group (NCT00382018). The trial showed no survival benefit for an early change of chemotherapy in patients with persistent or increased CTC counts following initial therapy [166]. The other trials focused on monitoring CTC count in MBC are ongoing. For example, the aim of the French CirCé01 trial (Circulating Tumor Cells to Guide Chemotherapy for Metastatic Breast Cancer; NCT01349842) is to evaluate repeatedly over several lines of chemotherapy whether patients whose CTC count does not decrease after the first treatment cycle benefit from a switch of chemotherapeutic regimens. In another French trial, the STIC CTC trial (NCT01710605), patients with hormone receptorpositive $\mathrm{MBC}$ are randomized between a standard clinician choice arm and a CTC count-driven arm.

Not only CTC count, but also CTC phenotype can be targeted. Preclinical and clinical data suggest that it is worth exploring the role of anti-HER2 strategies in women with HER2 nonamplified primary BC and detectable CTCs [167]. A single-center, randomized phase 2 study demonstrated the effectiveness of trastuzumab in eliminating CK19 mRNA-positive CTCs in BC patients after

Pathobiology 2017;84:264-283

DOI: $10.1159 / 000477812$ 
prior chemotherapy exposure [168]. Furthermore the same group evaluated the efficacy of lapatinib, a dual EGFR and HER2 tyrosine kinase inhibitor, in therapyresistant HER2-positive CTCs in MBC in a phase 2 single-center study (NCT00694252). Lapatinib was effective in decreasing HER2-positive CTC counts in patients with MBC, irrespectively of the HER2 status of the primary tumor [169]. Two prospective trials are currently ongoing to demonstrate the clinical benefit of anti-HER2 therapy in patients with MBC considered as HER2-negative and HER2-positive CTCs. The German DETECTIII study is a phase 3 study, comparing the lapatinib and chemotherapy combination versus chemotherapy alone in patients having at least 1 CTC with strong HER2 immunocytofluorescence (NCT01619111). A recent update on this study stated that about $19 \%$ of HER2-negative MBC patients were screened with at least 1 CTC with strong HER2 fluorescence [13]. The French CirCe T-DM1 (trastuzumab emtansine) study is a single-arm phase 2 study in which MBC patients with HER2-amplified CTCs receive T-DM1 as single therapy (NCT01975142). In this study, the discrepancy rate (patients with HER2-negative BC harboring HER2-positive CTCs) is lower than in the DETECTIII trial, around 5-8\% [13].

Although there are several ongoing trials investigating the role of CTCs as a decision tool in $\mathrm{MBC}$, there is only 1 trial on the clinical utility of CTCs in early BC, the EORTC Treat CTC trial. This trial is evaluating the efficacy of trastuzumab in patients with nonmetastatic HER2-negative disease and at least 1 CTC. The recent update of the trial showed that real-time screening of patients with early BC for CTCs, in the context of an international, multilaboratory trial, is feasible; first 26 patients were randomized [167].

The majority of described clinical trials are ongoing. The results of these trials will be crucial for evaluating the potential for CTC implementation in clinical BC management.

Recently a few preclinical studies reported the possibility of targeting EMT as the efficient way to inhibit metastasis. Suppression of MAPK7 kinase, responsible for maintaining mesenchymal cell properties in cancer cells, reduced the generation of CTCs and the appearance of lung metastases in a xenograft model of NOD scid gamma mice injected with the MDA-MB-231 BC cell line [170]. Forcing cancer cells in the mesenchymal state to revert to the epithelial one (MET) with forskolin or cholera toxin was shown to reduce the frequency of stem cell markers and increase their sensitivity to a range of drugs - doxorubicin, paclitaxel, proteasome inhibitors and MAPK/EGFR inhibitors [101]. Eribulin, a nontaxane microtubule dynamics inhibitor, induced a phenotypic switch from mesenchymal to epithelial states (MET), which was accompanied by decreased migration and invasiveness in vitro and decreased lung metastases and prolonged survival in an Mx-1 BC cell experimental metastasis model in vivo [171]. MET induced by eribulin was due to downregulation of the TGF- $\beta$ /SMAD pathway [171].

Targeting Tumor-Specific Microenvironment

While relying on a surface receptor to target CTCs can be greatly challenged by cancer heterogeneity, targeting of tumor microenvironments has the advantage of recognizing a broader spectrum of cancer cells regardless of genetic differences or tumor types.

Since tumor cell interactions with host cells in the microenvironment also seem to be critical during CTC dissemination and travel through the circulation, many new strategies targeting these interactions are currently investigated. Targeting platelet-tumor cell interaction is one of the most promising strategies to reduce distant metastasis. One approach to minimize these interactions has focused on the use of anticoagulation agents. Agents such as recombinant mouse tissue factor pathway inhibitor [172] and the platelet aggregation inhibitor cilostazol [173] have been found to reduce the formation of secondary metastases. Several studies suggest that heparin, a powerful P-selectin inhibitor, can attenuate tumor metastasis in mice [174]. However, the use of anticoagulants may also adversely affect the normal hemostatic function of platelets in the case of bleeding. Therefore, a more focused approach aiming to block the signaling between platelets and CTCs is being developed. Invasive behavior can be induced by transforming growth factor- $\beta_{1}$ (TGF- $\beta_{1}$ ), which is secreted by activated platelets. Temporary contact with platelets is sufficient to induce invasive behavior in CTCs through TGF- $\beta_{1}$ [67]. Blockage of TGF- $\beta_{1}$ receptor I kinase activity through the use of SD208 , a small-molecule inhibitor, was shown to prevent the development of TGF- $\beta$-induced bone metastases in a melanoma mouse model [175]. Similarly, the use of another TGF- $\beta_{1}$ receptor inhibitor, IN-1130, suppressed EMT and the lung metastasis of mammary tumors in mouse models [176]. Accumulating data suggest that aspirin may act as an inhibitor of cancer metastasis, and the chemotherapeutic effects of aspirin on the metastatic process may depend on the inhibition of platelet function. In an analysis of 5 randomized trials in the UK on daily aspirin use at $\geq 75 \mathrm{mg}$, the risk of cancer with distant
276

Pathobiology 2017;84:264-283

DOI: $10.1159 / 000477812$
Markiewicz/Żaczek 
metastases was also reduced [177]. Aspirin has been hypothesized to inhibit platelet-induced EMT of CTCs through the COX-1 signaling pathway, which may contribute to its antimetastatic effect [178]. Importantly, depletion of platelets or inhibition of TGF- $\beta$ secretion solely in platelets drastically reduced distant metastases [67]. Another way to target CTC-platelet interactions could be targeted drug delivery to CTCs via platelet membranefunctionalized particles, as shown for a major tumor-killing cytokine, tumor necrosis factor-related apoptosis-inducing ligand (TRAIL), conjugated to the platelet membrane-coated silica particles which dramatically decreased lung metastases in a mouse BC metastasis model [179]. Taking into account the presented data, platelets are a promising therapeutic target for the attenuation of metastatic events.

\section{Conclusion}

As CTCs contribute to a large extent to metastasis formation, it is vitally important to characterize and treat them as accurately as possible, to increase the therapeutic efficiency and to reduce side effects. Exploring EMT processes also conveys chances for tumor therapy. EMT and the signal transduction pathways within this process might serve as potent targets for therapeutic approaches. Inhibiting these signal transduction cascades by specifically tailored drugs could help to diminish or even abolish metastasis formation, maybe even without doing harm to healthy cells. Analyzing and understanding the mechanisms which lead to EMT, especially in CTCs, which are the main root of remote metastasis formation, could therefore give rise to new treatment strategies. The relative rarity of CTCs in patients, especially at early disease stages, should also bring our attention to the representativeness of molecular characteristics of the few captured cells. Single-cell genomics [180-183] and transcriptomics $[41,138,180,182,184]$ revealed significant interpatient molecular heterogeneity among CTCs.

We are beginning to explore the complex underlying mechanisms which lead from tumor cell dissociation from the primary tumor through EMT towards the formation of metastasis. Considering the described differences between epithelial and mesenchymal CTCs in therapy sensitivity, immune evasion, survival, and proliferative adventures, a detailed analysis of individual CTC phenotypes in cancer patients might offer promising perspectives for the future of personalized therapies.

\section{Acknowledgments}

This work was financed by the Ministry of Science and Higher Education program "Iuventus Plus" No. IP 2014 028473, between 2015 and 2018, and by grant No. 2016/22/E/NZ4/00664 from the National Science Centre, Poland. Aleksandra Markiewicz was supported by the Foundation for Polish Science (FNP).

\section{References}

1 Chaffer CL, Brueckmann I, Scheel C, Kaestli AJ, Wiggins PA, Rodrigues LO, Brooks M, Reinhardt F, Su Y, Polyak K, Arendt LM, Kuperwasser C, Bierie B, Weinberg RA: Normal and neoplastic nonstem cells can spontaneously convert to a stem-like state. Proc Natl Acad Sci USA 2011;108:7950-7955.

2 Kalluri R: Emt: When epithelial cells decide to become mesenchymal-like cells. J Clin Invest 2009;119:1417-1419.

3 Ksiazkiewicz M, Markiewicz A, Zaczek AJ: Epithelial-mesenchymal transition: a hallmark in metastasis formation linking circulating tumor cells and cancer stem cells. Pathobiology 2012;79:195-208.

4 Gradilone A, Raimondi C, Nicolazzo C, Petracca A, Gandini O, Vincenzi B: Circulating tumour cells lacking cytokeratin in breast cancer: the importance of being mesenchymal. J Cell Mol Med 2011;15:1066-1070.
5 Allard WJ, Matera J, Miller MC, Repollet M, Connelly MC, Rao C, Tibbe AGJ, Uhr JW, Terstappen LWMM: Tumor cells circulate in the peripheral blood of all major carcinomas but not in healthy subjects or patients with nonmalignant diseases. Clin Cancer Res 2004; 10:6897-6904.

6 Cristofanilli M, Budd G, Ellis M, Stopeck A, Matera J, Miller M, Reuben J, Doyle G, Allard W, Terstappen L, Hayes D: Circulating tumour cells, disease progression and survival in metastatic breast cancer. N Engl J Med 2004;351:781-791.

7 Rack B, Schindlbeck C, Jückstock J, Andergassen U, Hepp P, Zwingers T, Friedl TWP, Lorenz R, Tesch H, Fasching PA, Fehm T, Schneeweiss A, Lichtenegger W, Beckmann MW, Friese K, Pantel K, Janni W; SUCCESS Study Group: Circulating tumor cells predict survival in early average-to-high risk breast cancer patients. J Natl Cancer Inst 2014;106: dju066.
8 Janni W, Rack B, Terstappen LWMM, Pierga J-Y, Taran F-A, Fehm T, Hall C, de Groot M, Bidard F-C, Friedl TWP, Fasching PA, Brucker SY, Pantel K, Lucci A: Pooled analysis of the prognostic relevance of circulating tumor cells in primary breast cancer. Clin Cancer Res 2016;22:2583-2593.

9 Bidard F-C, Peeters DJ, Fehm T, Nolé F, Gisbert-Criado R, Mavroudis D, Grisanti S, Generali D, Garcia-Saenz JA, Stebbing J, Caldas C, Gazzaniga P, Manso L, Zamarchi R, de Lascoiti AF, De Mattos-Arruda L, Ignatiadis M, Lebofsky R, van Laere SJ, Meier-Stiegen F, Sandri M-T, Vidal-Martinez J, Politaki E, Consoli F, Bottini A, Diaz-Rubio E, Krell J, Dawson S-J, Raimondi C, Rutten A, et al: Clinical validity of circulating tumour cells in patients with metastatic breast cancer: a pooled analysis of individual patient data. Lancet Oncol 2014;15:406-414.
Circulating Tumor Cell Research and Epithelial-Mesenchymal Transition
Pathobiology 2017;84:264-283 DOI: $10.1159 / 000477812$ 
10 De Bono J, Scher H, Montgomery R, Parker C, Miller M, Tissing H, Doyle G, Terstappen L, Pienta K, Raghavan D: Circulating tumour cells predict survival benefit from treatment in metastatic castration-resistant prostate cancer. Clin Cancer Res 2008;14:6302-6309.

11 Cohen S, Punt C, Iannotti N, Saidman B, Sabbath K, Gabrail N, Picus J, Morse M, Mitchell E, Miller M, Doyle G, Tissing H, Terstappen L, Meropol N: Prognostic significance of circulating tumour cells in patients with metastatic colorectal cancer. Ann Oncol 2009;20: 1223-1229.

12 Krebs MG, Sloane R, Priest L, Lancashire L, Hou J-M, Greystoke A, Ward TH, Ferraldeschi R, Hughes A, Clack G, Ranson M, Dive C, Blackhall FH: Evaluation and prognostic significance of circulating tumor cells in patients with non-small-cell lung cancer. J Clin Oncol 2011;29:1556-1563.

13 Bidard F-C, Proudhon C, Pierga J-Y: Circulating tumor cells in breast cancer. Mol Oncol 2016;10:418-430.

14 Stott SL, Lee RJ, Nagrath S, Yu M, Miyamoto DT, Ulkus L, Inserra EJ, Ulman M, Springer S, Nakamura Z, Moore AL, Tsukrov DI, Kempner ME, Dahl DM, Wu CL, Iafrate AJ, Smith MR, Tompkins RG, Sequist LV, Toner M, Haber DA, Maheswaran S: Isolation and characterization of circulating tumor cells from patients with localized and metastatic prostate cancer. Sci Transl Med 2010;2: $25 \mathrm{ra23.}$

15 Baccelli I, Schneeweiss A, Riethdorf S, Stenzinger A, Schillert A, Vogel V, Klein C, Saini M, Bauerle T, Wallwiener M, Holland-Letz T, Hofner T, Sprick M, Scharpff M, Marme F, Sinn HP, Pantel K, Weichert W, Trumpp A: Identification of a population of blood circulating tumor cells from breast cancer patients that initiates metastasis in a xenograft assay. Nat Biotechnol 2013;31:539-544.

16 Zhang L, Ridgway LD, Wetzel MD, Ngo J, Yin W, Kumar D, Goodman JC, Groves MD, Marchetti D: The identification and characterization of breast cancer CTCs competent for brain metastasis. Sci Transl Med 2013;5: 180ra148.

17 Paget S: The distribution of secondary growths in cancer of the breast. Lancet 1889; 133:571-573.

18 Mego M, De Giorgi U, Dawood S, Wang X, Valero V, Andreopoulou E, Handy B, Ueno NT, Reuben JM, Cristofanilli M: Characterization of metastatic breast cancer patients with nondetectable circulating tumor cells. Int J Cancer 2011;129:417-423.

19 Yu M, Bardia A, Wittner BS, Stott SL, Smas ME, Ting DT, Isakoff SJ, Ciciliano JC, Wells MN, Shah AM, Concannon KF, Donaldson MC, Sequist LV, Brachtel E, Sgroi D, Baselga J, Ramaswamy S, Toner M, Haber DA, Maheswaran S: Circulating breast tumor cells exhibit dynamic changes in epithelial and mesenchymal composition. Science 2013;339:580-584.

20 Markiewicz A, Ksiazkiewicz M, WelnickaJaskiewicz M, Seroczynska B, Skokowski J,
Szade J, Zaczek AJ: Mesenchymal phenotype of CTC-enriched blood fraction and lymph node metastasis formation potential. PLoS One 2014;9:e93901.

21 Gal A, Sjöblom T, Fedorova L, Imreh S, Beug H, Moustakas A: Sustained TGF beta exposure suppresses SMAD and non-SMAD signalling in mammary epithelial cells, leading to EMT and inhibition of growth arrest and apoptosis. Oncogene 2008;27:1218-1230.

22 Fischer KR, Durrans A, Lee S, Sheng J, Li F, Wong ST, Choi H, El Rayes T, Ryu S, Troeger J, Schwabe RF, Vahdat LT, Altorki NK, Mittal V, Gao D: Epithelial-to-mesenchymal transition is not required for lung metastasis but contributes to chemoresistance. Nature 2015; 527:472-476.

23 Ye X, Weinberg RA: Epithelial-mesenchymal plasticity: a central regulator of cancer progression. Trends Cell Biol 2015;25:675-686.

24 Haviv I, Thompson EW: Soiling the seed: microenvironment and epithelial mesenchymal plasticity. Cancer Microenviron 2012;5:1-3.

25 Pepper MS, Skobe M: Lymphatic endothelium: morphological, molecular and functional properties. J Cell Biol 2003;163:209-213.

26 Swartz MA, Lund AW: Lymphatic and interstitial flow in the tumour microenvironment: linking mechanobiology with immunity. Nat Rev Cancer 2012;12:210-219.

27 Pepper MS, Skobe M: Lymphatic endothelium: morphological, molecular and functional properties. J Cell Biol 2003;163:209-213.

28 Sleeman JP, Krishnan J, Kirkin V, Baumann P: Markers for the lymphatic endothelium: in search of the holy grail? Microsc Res Technol 2001;55:61-69.

29 Piccinin S, Tonin E, Sessa S, Demontis S, Rossi S, Pecciarini L, Zanatta L, Pivetta F, Grizzo A, Sonego M, Rosano C, Dei Tos AP, Doglioni C, Maestro R: A "twist box" code of p53 inactivation: twist box: p53 interaction promotes p53 degradation. Cancer Cell 2012;22:404-415.

30 Ansieau S, Bastid J, Doreau A, Morel AP, Bouchet BP, Thomas C, Fauvet F, Puisieux I, Doglioni C, Piccinin S, Maestro R, Voeltzel T, Selmi A, Valsesia-Wittmann S, Caron de Fromentel C, Puisieux A: Induction of EMT by twist proteins as a collateral effect of tumorpromoting inactivation of premature senescence. Cancer Cell 2008;14:79-89.

31 Valsesia-Wittmann S, Magdeleine M, Dupasquier S, Garin E, Jallas AC, Combaret V, Krause A, Leissner P, Puisieux A: Oncogenic cooperation between $\mathrm{H}$-Twist and N-Myc overrides failsafe programs in cancer cells. Cancer Cell 2004;6:625-630.

32 Lee SH, Lee SJ, Jung YS, Xu Y, Kang HS, Ha NC, Park BJ: Blocking of p53-Snail binding, promoted by oncogenic K-Ras, recovers p53 expression and function. Neoplasia 2009;11: 22-31.

33 Wu WS, Heinrichs S, Xu D, Garrison SP, Zambetti GP, Adams JM, Look AT: Slug antagonizes p53-mediated apoptosis of hematopoietic progenitors by repressing puma. Cell 2005; 123:641-653.
34 Ni T, Li XY, Lu N, An T, Liu ZP, Fu R, Lv WC, Zhang YW, Xu XJ, Grant Rowe R, Lin YS, Scherer A, Feinberg T, Zheng XQ, Chen BA, Liu XS, Guo QL, Wu ZQ, Weiss SJ: Snail1dependent p53 repression regulates expansion and activity of tumour-initiating cells in breast cancer. Nat Cell Biol 2016;18:12211232.

35 Beck B, Lapouge G, Rorive S, Drogat B, Desaedelaere K, Delafaille S, Dubois C, Salmon I, Willekens K, Marine JC, Blanpain C: Different levels of twist 1 regulate skin tumor initiation, stemness, and progression. Cell Stem Cell 2015;16:67-79.

36 Jolly MK, Boareto M, Huang B, Jia D, Lu M, Ben-Jacob E, Onuchic JN, Levine H: Implications of the hybrid epithelial/mesenchymal phenotype in metastasis. Front Oncol 2015;5: 155.

37 Ruscetti M, Quach B, Dadashian EL, Mulholland DJ, Wu H: Tracking and functional characterization of epithelial-mesenchymal transition and mesenchymal tumor cells during prostate cancer metastasis. Cancer Res 2015; 75:2749-2759.

38 Satelli A, Mitra A, Brownlee Z, Xia X, Bellister S, Overman MJ, Kopetz S, Ellis LM, Meng QH, Li S: Epithelial-mesenchymal transitioned circulating tumor cells capture for detecting tumor progression. Clin Cancer Res 2015;21:899-906.

39 Satelli A, Mitra A, Cutrera JJ, Devarie M, Xia $\mathrm{X}$, Ingram DR, Dibra D, Somaiah $\mathrm{N}$, Torres KE, Ravi V, Ludwig JA, Kleinerman ES, Li S: Universal marker and detection tool for human sarcoma circulating tumor cells. Cancer Res 2014;74:1645-1650.

40 Satelli A, Li S: Vimentin in cancer and its potential as a molecular target for cancer therapy. Cell Mol Life Sci 2011;68:3033-3046.

41 Chen CL, Mahalingam D, Osmulski P, Jadhav RR, Wang CM, Leach RJ, Chang TC, Weitman SD, Kumar AP, Sun L, Gaczynska ME, Thompson IM, Huang TH: Single-cell analysis of circulating tumor cells identifies cumulative expression patterns of EMT-related genes in metastatic prostate cancer. Prostate 2013;73:813-826.

42 Ueo H, Sugimachi K, Gorges TM, Bartkowiak K, Yokobori T, Müller V, Shinden Y, Ueda M, Mori M, Kuwano H, Maehara Y, Ohno S, Pantel K, Mimori K: Circulating tumour cellderived plastin 3 is a novel marker for predicting long-term prognosis in patients with breast cancer. Br J Cancer 2015;112:15191526.

43 Yokobori $\mathrm{T}$, Iinuma $\mathrm{H}$, Shimamura $\mathrm{T}$, Imoto S, Sugimachi K, Ishii H, Iwatsuki M, Ota D, Ohkuma M, Iwaya $T$, Nishida $N$, Kogo R, Sudo T, Tanaka F, Shibata K, Toh H, Sato T, Barnard GF, Fukagawa T, Yamamoto S, Nakanishi H, Sasaki S, Miyano S, Watanabe T, Kuwano H, Mimori K, Pantel K, Mori M: Plastin3 is a novel marker for circulating tumor cells undergoing the epithelial-mesenchymal transition and is associated with colorectal cancer prognosis. Cancer Res 2013;73:2059. 
44 Polioudaki H, Agelaki S, Chiotaki R, Politaki E, Mavroudis D, Matikas A, Georgoulias V, Theodoropoulos PA: Variable expression levels of keratin and vimentin reveal differential EMT status of circulating tumor cells and correlation with clinical characteristics and outcome of patients with metastatic breast cancer. BMC Cancer 2015;15:399.

45 Aceto N, Bardia A, Miyamoto DT, Donaldson MC, Wittner BS, Spencer JA, Yu M, Pely A, Engstrom A, Zhu H, Brannigan BW, Kapur R, Stott SL, Shioda T, Ramaswamy S, Ting DT, Lin CP, Toner M, Haber DA, Maheswaran S: Circulating tumor cell clusters are oligoclonal precursors of breast cancer metastasis. Cell 2014;158:1110-1122.

46 Ao Z, Shah SH, Machlin LM, Parajuli R, Miller PC, Rawal S, Williams AJ, Cote RJ, Lippman ME, Datar RH, El-Ashry D: Identification of cancer-associated fibroblasts in circulating blood from patients with metastatic breast cancer. Cancer Res 2015;75:4681-4687.

47 Cho EH, Wendel M, Luttgen M, Yoshioka C, Marrinucci D, Lazar D, Schram E, Nieva J, Bazhenova L, Morgan A, Ko AH, Korn WM, Kolatkar A, Bethel K, Kuhn P: Characterization of circulating tumor cell aggregates identified in patients with epithelial tumors. Phys Biol 2012;9:016001-016001.

48 Molnar B, Ladanyi A, Tanko L, Sréter L, Tulassay Z: Circulating tumor cell clusters in the peripheral blood of colorectal cancer patients. Am Assoc Cancer Res 2001;7:4080-4085.

49 Fidler IJ: The relationship of embolic homogeneity, number, size and viability to the incidence of experimental metastasis. Eur J Cancer (1965) 1973;9:223-227.

50 Liotta LA, Kleinerman J, Saldel GM: The significance of hematogenous tumor cell clumps in the metastatic process. Cancer Res 1976;36: 889-894.

51 Gundem G, Van Loo P, Kremeyer B, Alexandrov LB, Tubio JMC, Papaemmanuil E, Brewer DS, Kallio HML, Högnäs G, Annala M, Kivinummi K, Goody V, Latimer C, O’Meara S, Dawson KJ, Isaacs W, Emmert-Buck MR, Nykter M, Foster C, Kote-Jarai Z, Easton D, Whitaker HC, Group IP, Neal DE, Cooper CS, Eeles RA, Visakorpi T, Campbell PJ, McDermott U, Wedge DC, Bova GS: The evolutionary history of lethal metastatic prostate cancer. Nature 2015;520:353-357.

52 Maddipati R, Stanger BZ: Pancreatic cancer metastases harbor evidence of polyclonality. Cancer Discov 2015;5:1086-1097.

53 Cheung KJ, Padmanaban V, Silvestri V, Schipper K, Cohen JD, Fairchild AN, Gorin MA, Verdone JE, Pienta KJ, Bader JS, Ewald AJ: Polyclonal breast cancer metastases arise from collective dissemination of keratin 14-expressing tumor cell clusters. Proc Natl Acad Sci USA 2016;113:E854-E863.

54 Hou J-M, Krebs MG, Lancashire L, Sloane R, Backen A, Swain RK, Priest LJC, Greystoke A, Zhou C, Morris K, Ward T, Blackhall FH, Dive C: Clinical significance and molecular characteristics of circulating tumor cells and circulating tumor microemboli in patients with small-cell lung cancer. J Clin Oncol 2012; 30:525-532.

55 Thiery JP, Acloque H, Huang RY, Nieto MA: Epithelial-mesenchymal transitions in development and disease. Cell 2009;139:871-890.

56 Sigurdsson V, Hilmarsdottir B, Sigmundsdottir H, Fridriksdottir AJR, Ringnér M, Villadsen R, Borg A, Agnarsson BA, Petersen OW, Magnusson MK, Gudjonsson T: Endothelial induced EMT in breast epithelial cells with stem cell properties. PLoS One 2011;6: e23833.

57 Lou X-L, Sun J, Gong S-Q, Yu X-F, Gong R, Deng H: Interaction between circulating cancer cells and platelets: clinical implication. Chin J Cancer Res 2015;27:450-460.

58 Noble S, Pasi J: Epidemiology and pathophysiology of cancer-associated thrombosis. Br J Cancer 2010;102:S2-S9.

59 David M, Ribeiro J, Descotes F, Serre CM, Barbier M, Murone M, Clézardin P, Peyruchaud O: Targeting lysophosphatidic acid receptor type 1 with debio 0719 inhibits spontaneous metastasis dissemination of breast cancer cells independently of cell proliferation and angiogenesis. Int J Oncol 2012;40: 1133-1141.

60 Yu S, Murph M, Lu Y, Liu S, Hall H, Liu J, Stephens C, Fang X, Mills G: Lysophosphatidic acid receptors determine tumorigenicity and aggressiveness of ovarian cancer cells. J Natl Cancer Inst 2008;100:1630-1642.

61 Nieswandt B, Hafner M, Echtenacher B, Männel DN: Lysis of tumor cells by natural killer cells in mice is impeded by platelets. Cancer Res 1999;59:1295-1300.

62 Palumbo JS, Talmage KE, Massari JV, La Jeunesse CM, Flick MJ, Kombrinck KW, Jirousková M, Degen JL: Platelets and fibrin(ogen) increase metastatic potential by impeding natural killer cell-mediated elimination of tumor cells. Blood 2005;105:178-185.

63 Radziwon-Balicka A, Medina C, O’Driscoll L, Treumann A, Bazou D, Inkielewicz-Stepniak I, Radomski A, Jow H, Radomski MW: Platelets increase survival of adenocarcinoma cells challenged with anticancer drugs: mechanisms and implications for chemoresistance. Br J Pharmacol 2012;167:787-804.

64 Velez J, Enciso LJ, Suarez M, Fiegl M, Grismaldo A, López C, Barreto A, Cardozo C, Palacios P, Morales L, Duque JE, Carmona JU, Konopleva M, Andreeff M, Samudio I: Platelets promote mitochondrial uncoupling and resistance to apoptosis in leukemia cells: a novel paradigm for the bone marrow microenvironment. Cancer Microenviron 2014;7:7990.

65 Labelle M, Hynes RO: The initial hours of metastasis: the importance of cooperative hosttumor cell interactions during hematogenous dissemination. Cancer Discov 2012;2:10911099.

66 Franco AT, Corken A, Ware J: Platelets at the interface of thrombosis, inflammation, and cancer. Blood 2015;126:582-588.
67 Labelle M, Begum S, Hynes RO: Direct signaling between platelets and cancer cells induces an epithelial-mesenchymal-like transition and promotes metastasis. Cancer Cell 2011; 20:576-590.

68 Meng S, Tripathy D, Frenkel EP, Shete S, Naftalis EZ, Huth JF, Beitsch PD, Leitch M, Hoover S, Euhus D, Haley B, Morrison L, Fleming TP, Herlyn D, Terstappen LW, Fehm T, Tucker TF, Lane N, Wang J, Uhr JW: Circulating tumor cells in patients with breast cancer dormancy. Clin Cancer Res 2004;10: 8152-8162.

69 Beerling E, Seinstra D, de Wit E, Kester L, van der Velden D, Maynard C, Schäfer R, van Diest $\mathrm{P}$, Voest E, van Oudenaarden A, Vrisekoop $\mathrm{N}$, van Rheenen J: Plasticity between epithelial and mesenchymal states unlinks EMT from metastasis-enhancing stem cell capacity. Cell Rep 2016;14:2281-2288.

70 Gao MQ, Kim BG, Kang S, Choi YP, Park H, Kang KS, Cho NH: Stromal fibroblasts from the interface zone of human breast carcinomas induce an epithelial-mesenchymal transition-like state in breast cancer cells in vitro. J Cell Sci 2010;123:3507-3514.

71 Soon PS, Kim E, Pon CK, Gill AJ, Moore K, Spillane AJ, Benn DE, Baxter RC: Breast cancer-associated fibroblasts induce epithelialto-mesenchymal transition in breast cancer cells. Endocr Relat Cancer 2013;20:1-12.

72 Duda DG, Duyverman AM, Kohno M, Snuderl M, Steller EJ, Fukumura D, Jain RK: Malignant cells facilitate lung metastasis by bringing their own soil. Proc Natl Acad Sci USA 2010;107:21677-21682.

73 Rhim AD, Mirek ET, Aiello NM, Maitra A, Bailey JM, McAllister F, Reichert M, Beatty GL, Rustgi AK, Vonderheide RH, Leach SD, Stanger BZ: EMT and dissemination precede pancreatic tumor formation. Cell 2012;148: 349-361.

74 Hüsemann Y, Geigl JB, Schubert F, Musiani P, Meyer M, Burghart E, Forni G, Eils R, Fehm T, Riethmüller G, Klein CA: Systemic spread is an early step in breast cancer. Cancer Cell 2008; 13:58-68.

75 Tsai JH, Donaher JL, Murphy DA, Chau S, Yang J: Spatiotemporal regulation of epithelial-mesenchymal transition is essential for squamous cell carcinoma metastasis. Cancer Cell 2012;22:725-736.

76 Bonnomet A, Syne L, Brysse A, Feyereisen E, Thompson EW, Noel A, Foidart JM, Birembaut $\mathrm{P}$, Polette $\mathrm{M}$, Gilles $\mathrm{C}$ : A dynamic in vivo model of epithelial-to-mesenchymal transitions in circulating tumor cells and metastases of breast cancer. Oncogene 2012;31:37413753.

77 Korpal M, Ell BJ, Buffa FM, Ibrahim T, Blanco MA, Celià-Terrassa T, Mercatali L, Khan Z, Goodarzi H, Hua Y, Wei Y, Hu G, Garcia BA, Ragoussis J, Amadori D, Harris AL, Kang Y: Direct targeting of sec23a by mir-200s influences cancer cell secretome and promotes metastatic colonization. Nat Med 2011;17: 1101-1108.
Circulating Tumor Cell Research and Epithelial-Mesenchymal Transition
Pathobiology 2017;84:264-283

DOI: $10.1159 / 000477812$ 
78 Herschkowitz JI, Simin K, Weigman VJ, Mikaelian I, Usary J, Hu Z, Rasmussen KE, Jones LP, Assefnia S, Chandrasekharan S, Backlund MG, Yin Y, Khramtsov AI, Bastein R, Quackenbush J, Glazer RI, Brown PH, Green JE, Kopelovich L, Furth PA, Palazzo JP, Olopade OI, Bernard PS, Churchill GA, Van Dyke T, Perou CM: Identification of conserved gene expression features between murine mammary carcinoma models and human breast tumors. Genome Biol 2007;8:R76.

79 Tsuji T, Ibaragi S, Hu GF: Epithelial-mesenchymal transition and cell cooperativity in metastasis. Cancer Res 2009;69:7135-7139.

80 Celià-Terrassa T, Meca-Cortés O, Mateo F, Martínez de Paz A, Rubio N, Arnal-Estapé A, Ell BJ, Bermudo R, Díaz A, Guerra-Rebollo M, Lozano JJ, Estarás C, Ulloa C, ÁlvarezSimón D, Milà J, Vilella R, Paciucci R, Martínez-Balbás M, de Herreros AG, Gomis RR, Kang Y, Blanco J, Fernández PL, Thomson TM: Epithelial-mesenchymal transition can suppress major attributes of human epithelial tumor-initiating cells. J Clin Invest 2012;122: 1849-1868.

81 Clevers H: Stem cells: a unifying theory for the crypt. Nature 2013;495:53-54.

82 Tumbar T, Guasch G, Greco V, Blanpain C, Lowry WE, Rendl M, Fuchs E: Defining the epithelial stem cell niche in skin. Science 2004;303:359-363.

83 Welm BE, Tepera SB, Venezia T, Graubert TA, Rosen JM, Goodell MA: SCA-1(pos) cells in the mouse mammary gland represent an enriched progenitor cell population. Dev Biol 2002;245:42-56.

84 Urbanek K, Cesselli D, Rota M, Nascimbene A, De Angelis A, Hosoda T, Bearzi C, Boni A, Bolli R, Kajstura J, Anversa P, Leri A: Stem cell niches in the adult mouse heart. Proc Natl Acad Sci USA 2006;103:9226-9231.

85 Zhang J, Niu C, Ye L, Huang H, He X, Tong WG, Ross J, Haug J, Johnson T, Feng JQ, Harris S, Wiedemann LM, Mishina Y, Li L: Identification of the haematopoietic stem cell niche and control of the niche size. Nature 2003;425:836-841.

86 Foudi A, Hochedlinger K, Van Buren D, Schindler JW, Jaenisch R, Carey V, Hock H: Analysis of histone 2b-GFP retention reveals slowly cycling hematopoietic stem cells. Nat Biotechnol 2009;27:84-90.

87 Reya T, Morrison SJ, Clarke MF, Weissman IL: Stem cells, cancer, and cancer stem cells. Nature 2001;414:105-111.

88 Clarke MF, Dick JE, Dirks PB, Eaves CJ, Jamieson $\mathrm{CH}$, Jones DL, Visvader J, Weissman IL, Wahl GM: Cancer stem cells - perspectives on current status and future directions: AACR workshop on cancer stem cells. Cancer Res 2006;66:9339-9344.

89 Medema JP: Cancer stem cells: the challenges ahead. Nat Cell Biol 2013;15:338-344.

90 Morel AP, Lièvre M, Thomas C, Hinkal G, Ansieau S, Puisieux A: Generation of breast cancer stem cells through epithelial-mesenchymal transition. PLoS One 2008;3:e2888.
91 Mani SA, Guo W, Liao MJ, Eaton EN, Ayyanan A, Zhou AY: The epithelial-mesenchymal transition generates cells with properties of stem cells. Cell 2008;133:704-715.

92 Santisteban M, Reiman JM, Asiedu MK, Behrens MD, Nassar A, Kalli KR, Haluska P, Ingle JN, Hartmann LC, Manjili MH, Radisky DC, Ferrone S, Knutson KL: Immuneinduced epithelial to mesenchymal transition in vivo generates breast cancer stem cells. Cancer Res 2009;69:2887-2895.

93 Chaffer CL, Marjanovic ND, Lee T, Bell G, Kleer CG, Reinhardt F, D’Alessio AC, Young RA, Weinberg RA: Poised chromatin at the zeb1 promoter enables breast cancer cell plasticity and enhances tumorigenicity. Cell 2013;154:61-74.

94 Liu S, Cong Y, Wang D, Sun Y, Deng L, Liu Y, Martin-Trevino R, Shang L, McDermott SP, Landis MD, Hong S, Adams A, D'Angelo R, Ginestier C, Charafe-Jauffret E, Clouthier SG, Birnbaum D, Wong ST, Zhan M, Chang JC, Wicha MS: Breast cancer stem cells transition between epithelial and mesenchymal states reflective of their normal counterparts. Stem Cell Rep 2014;2:78-91.

95 Markiewicz A, Welnicka-Jaskiewicz M, Seroczynska B, Skokowski J, Majewska H, Szade J, Zaczek AJ: Epithelial-mesenchymal transition markers in lymph node metastases and primary breast tumors - relation to dissemination and proliferation. Am J Transl Res 2014;6:793-808.

96 Imai T, Horiuchi A, Shiozawa T, Osada R, Kikuchi N, Ohira S, Oka K, Konishi I: Elevated expression of E-cadherin and alpha-, beta-, and gamma-catenins in metastatic lesions compared with primary epithelial ovarian carcinomas. Hum Pathol 2004;35: 1469-1476.

97 Kowalski PJ, Rubin MA, Kleer CG: E-cadherin expression in primary carcinomas of the breast and its distant metastases. Breast Cancer Res 2003;5:R217-R222.

98 Rubin MA, Mucci NR, Figurski J, Fecko A, Pienta KJ, Day ML: E-cadherin expression in prostate cancer: a broad survey using highdensity tissue microarray technology. Hum Pathol 2001;32:690-697.

99 Del Pozo Martin Y, Park D, Ramachandran A, Ombrato L, Calvo F, Chakravarty P, Spencer-Dene B, Derzsi S, Hill CS, Sahai E, Malanchi I: Mesenchymal cancer cell-stroma crosstalk promotes niche activation, epithelial reversion, and metastatic colonization. Cell Rep 2015;13:2456-2469.

100 Headley MB, Bins A, Nip A, Roberts EW, Looney MR, Gerard A, Krummel MF: Visualization of immediate immune responses to pioneer metastatic cells in the lung. Nature 2016;531:513-517.

101 Pattabiraman DR, Bierie B, Kober KI, Thiru P, Krall JA, Zill C, Reinhardt F, Tam WL, Weinberg RA: Activation of PKA leads to mesenchymal-to-epithelial transition and loss of tumor-initiating ability. Science 2016; 351:aad3680.
102 Brichard V, Van Pel A, Wölfel T, Wölfel C, De Plaen E, Lethé B, Coulie P, Boon T: The tyrosinase gene codes for an antigen recognized by autologous cytolytic $\mathrm{T}$ lymphocytes on HLA-A2 melanomas. J Exp Med 1993; 178:489-495.

103 Topalian SL, Rivoltini L, Mancini M, Markus NR, Robbins PF, Kawakami Y, Rosenberg SA: Human CD4+ T cells specifically recognize a shared melanoma-associated antigen encoded by the tyrosinase gene. Proc Natl Acad Sci USA 1994;91:9461-9465.

104 Wang RF, Appella E, Kawakami Y, Kang X, Rosenberg SA: Identification of TRP-2 as a human tumor antigen recognized by cytotoxic T lymphocytes. J Exp Med 1996;184: 2207-2216.

105 Bakker AB, Schreurs MW, de Boer AJ, Kawakami Y, Rosenberg SA, Adema GJ, Figdor CG: Melanocyte lineage-specific antigen gp100 is recognized by melanoma-derived tumor-infiltrating lymphocytes. J Exp Med 1994;179:1005-1009.

106 Maio M: Melanoma as a model tumour for immuno-oncology. Ann Oncol 2012; 23(suppl 8):viii10-viiil4.

107 Landsberg J, Kohlmeyer J, Renn M, Bald T, Rogava M, Cron M, Fatho M, Lennerz V, Wölfel T, Hölzel M, Tüting T: Melanomas resist $\mathrm{T}$-cell therapy through inflammationinduced reversible dedifferentiation. Nature 2012;490:412-416.

108 Woods K, Pasam A, Jayachandran A, Andrews MC, Cebon J: Effects of epithelial to mesenchymal transition on T cell targeting of melanoma cells. Front Oncol 2014;4: 367.

109 Knutson KL, Lu H, Stone B, Reiman JM, Behrens MD, Prosperi CM, Gad EA, Smorlesi A, Disis ML: Immunoediting of cancers may lead to epithelial to mesenchymal transition. J Immunol 2006;177:1526-1533.

110 Tripathi SC, Peters HL, Taguchi A, Katayama H, Wang H, Momin A, Jolly MK, Celiktas M, Rodriguez-Canales J, Liu H, Behrens C, Wistuba II, Ben-Jacob E, Levine H, Molldrem JJ, Hanash SM, Ostrin EJ: Immunoproteasome deficiency is a feature of nonsmall cell lung cancer with a mesenchymal phenotype and is associated with a poor outcome. Proc Natl Acad Sci USA 2016;113: E1555-E1564.

111 Alsuliman A, Colak D, Al-Harazi O, Fitwi $\mathrm{H}$, Tulbah A, Al-Tweigeri T, Al-Alwan $\mathrm{M}$, Ghebeh H: Bidirectional crosstalk between PD-L1 expression and epithelial to mesenchymal transition: significance in claudinlow breast cancer cells. Mol Cancer 2015; 14: 149.

112 Zhi Y, Mou Z, Chen J, He Y, Dong H, Fu X, Wu Y: B7h1 expression and epithelial-tomesenchymal transition phenotypes on colorectal cancer stem-like cells. PLoS One 2015;10:e0135528. 
113 Ricciardi M, Zanotto M, Malpeli G, Bassi G, Perbellini O, Chilosi M, Bifari F, Krampera M: Epithelial-to-mesenchymal transition (EMT) induced by inflammatory priming elicits mesenchymal stromal cell-like immune-modulatory properties in cancer cells. Br J Cancer 2015;112:1067-1075.

114 Kudo-Saito C, Shirako H, Takeuchi T, Kawakami Y: Cancer metastasis is accelerated through immunosuppression during Snail-induced EMT of cancer cells. Cancer Cell 2009;15:195-206.

115 Flavell RA, Sanjabi S, Wrzesinski SH, Licona-Limón P: The polarization of immune cells in the tumour environment by TGFbeta. Nat Rev Immunol 2010;10:554-567.

116 Li MO, Wan YY, Sanjabi S, Robertson AK, Flavell RA: Transforming growth factor-beta regulation of immune responses. Annu Rev Immunol 2006;24:99-146.

117 Vivier E, Ugolini S, Blaise D, Chabannon C, Brossay L: Targeting natural killer cells and natural killer T cells in cancer. Nat Rev Immunol 2012;12:239-252.

118 Placke T, Örgel M, Schaller M, Jung G, Rammensee HG, Kopp HG, Salih HR: Plateletderived MHC class I confers a pseudonormal phenotype to cancer cells that subverts the antitumor reactivity of natural killer immune cells. Cancer Res 2012;72:440-448.

119 Leblanc R, Peyruchaud O: Metastasis: new functional implications of platelets and megakaryocytes. Blood 2016;128:24-31.

120 Chao MP, Weissman IL, Majeti R: The CD47-SIRPa pathway in cancer immune evasion and potential therapeutic implications. Curr Opin Immunol 2012;24:225232.

121 Yamauchi C, Fujii S, Kimura T, Kuwata T, Wada N, Mukai H, Matsumoto N, Fukayama M, Ochiai A: E-cadherin expression on human carcinoma cell affects trastuzumabmediated antibody-dependent cellular cytotoxicity through killer cell lectin-like receptor G1 on natural killer cells. Int J Cancer 2011;128:2125-2137.

122 Ashworth T: A case of cancer in which cells similar to those in the tumours were seen in the blood after death. Aus Med J 1869;14: 146-149.

123 Barriere G, Riouallon A, Renaudie J, Tartary M, Rigaud M: Mesenchymal and stemness circulating tumor cells in early breast cancer diagnosis. BMC Cancer 2012;12:114.

124 Aktas B, Tewes M, Fehm T, Hauch S, Kimmig R, Kasimir-Bauer S: Stem cell and epithelial-mesenchymal transition markers are frequently overexpressed in circulating tumor cells of metastatic breast cancer patients. Breast Cancer Res 2009;11:R46.

125 Kasimir-Bauer S, Hoffmann O, Wallwiener D, Kimmig R, Fehm T: Expression of stem cell and epithelial-mesenchymal transition markers in primary breast cancer patients with circulating tumor cells. Breast Cancer Res 2012;14:R15.
126 Raimondi C, Gradilone A, Naso G, Vincenzi B, Petracca A, Nicolazzo C: Epithelial-mesenchymal transition and stemness features in circulating tumor cells from breast cancer patients. Breast Cancer Res Treat 2011;130: 449-455.

127 Markou A, Strati A, Malamos N, Georgoulias V, Lianidou ES: Molecular characterization of circulating tumor cells in breast cancer by a liquid bead array hybridization assay. Clin Chem 2011;57:421.

128 Strati A, Markou A, Parisi C, Politaki E, Mavroudis D, Georgoulias V, Lianidou E: Gene expression profile of circulating tumor cells in breast cancer by rt-qPCR. BMC Cancer 2011;11:422.

129 Kallergi G, Papadaki M, Politaki E, Mavroudis D, Georgoulias V, Agelaki S: Epithelial to mesenchymal transition markers expressed in circulating tumour cells of early and metastatic breast cancer patients. Breast Cancer Res 2011;13:R59.

130 Papadaki MA, Kallergi G, Zafeiriou Z, Manouras L, Theodoropoulos PA, Mavroudis D, Georgoulias V, Agelaki S: Co-expression of putative stemness and epithelial-to-mesenchymal transition markers on single circulating tumour cells from patients with early and metastatic breast cancer. BMC Cancer 2014; 14:651.

131 Mego M, Gao H, Lee BN, Cohen EN, Tin S, Giordano A, Wu Q, Liu P, Nieto Y, Champlin RE, Hortobagyi GN, Cristofanilli M, Ueno NT, Reuben JM: Prognostic value of EMT-circulating tumor cells in metastatic breast cancer patients undergoing high-dose chemotherapy with autologous hematopoietic stem cell transplantation. J Cancer 2012; 3:369-380.

132 Ning Y, Zhang W, Hanna DL, Yang D, Okazaki S, Berger MD, Miyamoto Y, Suenaga M, Schirripa M, El-Khoueiry A, Lenz HJ: Clinical relevance of EMT and stem-like gene expression in circulating tumor cells of metastatic colorectal cancer patients. Pharmacogenomics J 2016, Epub ahead of print.

133 Li YM, Xu SC, Li J, Han KQ, Pi HF, Zheng L, Zuo GH, Huang XB, Li HY, Zhao HZ, Yu ZP, Zhou Z, Liang P: Epithelial-mesenchymal transition markers expressed in circulating tumor cells in hepatocellular carcinoma patients with different stages of disease. Cell Death Dis 2013;4:e831.

134 Liu Y-K, Hu B-S, Li Z-L, He X, Li Y, Lu L-G: An improved strategy to detect the epithelial-mesenchymal transition process in circulating tumor cells in hepatocellular carcinoma patients. Hepatol Int 2016;10:640-646.

135 Li T-T, Liu H, Li F-P, Hu Y-F, Mou T-Y, Lin T, Yu J, Zheng L, Li G-X: Evaluation of epithelial-mesenchymal transitioned circulating tumor cells in patients with resectable gastric cancer: relevance to therapy response. World J Gastroenterol 2015;21: 13259-13267.
136 Armstrong A, Marengo M, Oltean S, Kemeny G, Bitting R, Turnbull J, Herold C, Marcom P, George D, Garcia-Blanco M: Circulating tumour cells from patients with advanced prostate and breast cancer display both epithelial and mesenchymal markers. Mol Cancer Res 2011;9:997-1007.

137 Todenhöfer T, Hennenlotter J, Dorner N, Kühs U, Aufderklamm S, Rausch S, Bier S, Mischinger J, Schellbach D, Hauch S, Feniuk N, Bedke J, Gakis G, Stenzl A, Schwentner C: Transcripts of circulating tumor cells detected by a breast cancer-specific platform correlate with clinical stage in bladder cancer patients. J Cancer Res Clin Oncol 2016;142: 1013-1020.

138 Blassl C, Kuhlmann JD, Webers A, Wimberger P, Fehm T, Neubauer H: Gene expression profiling of single circulating tumor cells in ovarian cancer - establishment of a multi-marker gene panel. Mol Oncol 2016;10:1030-1042.

139 Alonso-Alconada L, Muinelo-Romay L, Madissoo K, Diaz-Lopez A, Krakstad C, Trovik J, Wik E, Hapangama D, Coenegrachts L, Cano A, Gil-Moreno A, Chiva L, Cueva J, Vieito M, Ortega E, Mariscal J, Colas E, Castellvi J, Cusido M, Dolcet X, Nijman HW, Bosse T, Green JA, Romano A, Reventos J, Lopez-Lopez R, Salvesen HB, Amant F, Matias-Guiu X, Moreno-Bueno G, Abal M: Molecular profiling of circulating tumor cells links plasticity to the metastatic process in endometrial cancer. Mol Cancer 2014;13:1-10.

140 Lecharpentier A, Vielh P, Perez-Moreno P, Planchard D, Soria JC, Farace F: Detection of circulating tumour cells with a hybrid (epithelial/mesenchymal) phenotype in patients with metastatic non-small cell lung cancer. Br J Cancer 2011;105:1338-1341.

141 Bednarz N, Eltze E, Semjonow A, Rink M, Andreas A, Mulder L, Hannemann J, Fisch M, Pantel K, Weier HU, Bielawski KP, Brandt B: Brcal loss preexisting in small subpopulations of prostate cancer is associated with advanced disease and metastatic spread to lymph nodes and peripheral blood. Clin Cancer Res 2010;16:3340-3348.

142 Bulfoni M, Gerratana L, Del Ben F, Marzinotto S, Sorrentino M, Turetta M, Scoles G, Toffoletto B, Isola M, Beltrami CA, Di Loreto C, Beltrami AP, Puglisi F, Cesselli D: In patients with metastatic breast cancer the identification of circulating tumor cells in epithelial-to-mesenchymal transition is associated with a poor prognosis. Breast Cancer Res 2016;18:30.

143 Martin OA, Anderson RL, Russell PA, Cox RA, Ivashkevich A, Swierczak A, Doherty JP, Jacobs DH, Smith J, Siva S, Daly PE, Ball DL, Martin RF, MacManus MP: Mobilization of viable tumor cells into the circulation during radiation therapy. Int J Radiat Oncol Biol Phys 2014;88:395-403.
Circulating Tumor Cell Research and

Epithelial-Mesenchymal Transition
Pathobiology 2017;84:264-283

DOI: $10.1159 / 000477812$ 
$144 \mathrm{Mu}$ Z, Wang C, Ye Z, Austin L, Civan J, Hyslop T, Palazzo JP, Jaslow R, Li B, Myers RE, Jiang J, Xing J, Yang H, Cristofanilli M: Prospective assessment of the prognostic value of circulating tumor cells and their clusters in patients with advanced-stage breast cancer. Breast Cancer Res Treat 2015;154:563-571.

145 Riethdorf S, Muller V, Zhang L, Rau T, Loibl S, Komor M, Roller M, Huober J, Fehm T, Schrader I, Hilfrich J, Holms F, Tesch H, Eidtmann H, Untch M, von Minckwitz G, Pantel K: Detection and HER2 expression of circulating tumor cells: prospective monitoring in breast cancer patients treated in the neoadjuvant GeparQuattro trial. Clin Cancer Res 2010;16:2634-2645.

146 Pachmann K, Camara O, Kavallaris A, Krauspe S, Malarski N, Gajda M, Kroll T, Jörke C, Hammer U, Altendorf-Hofmann A, Rabenstein C, Pachmann U, Runnebaum I, Höffken K: Monitoring the response of circulating epithelial tumor cells to adjuvant chemotherapy in breast cancer allows detection of patients at risk of early relapse. J Clin Oncol 2008;26:1208-1215.

147 Lucci A, Hall CS, Lodhi AK, Bhattacharyya A, Anderson AE, Xiao L, Bedrosian I, Kuerer HM, Krishnamurthy S: Circulating tumour cells in non-metastatic breast cancer: a prospective study. Lancet Oncol 2012;13: 688-695.

148 Hayes DF, Cristofanilli M, Budd GT, Ellis MJ, Stopeck A, Miller MC, Matera J, Allard WJ, Doyle GV, Terstappen LWWM: Circulating tumor cells at each follow-up time point during therapy of metastatic breast cancer patients predict progression-free and overall survival. Clin Cancer Res 2006;12: 4218-4224.

149 Liu MC, Shields PG, Warren RD, Cohen P, Wilkinson M, Ottaviano YL, Rao SB, EngWong J, Seillier-Moiseiwitsch F, Noone AM, Isaacs C: Circulating tumor cells: a useful predictor of treatment efficacy in metastatic breast cancer. J Clin Oncol 2009;27:51535159.

150 Nakamura S, Yagata H, Ohno S, Yamaguchi $\mathrm{H}$, Iwata $\mathrm{H}$, Tsunoda $\mathrm{N}$, Ito $\mathrm{Y}$, Tokudome $\mathrm{N}$, Toi M, Kuroi K, Suzuki E: Multi-center study evaluating circulating tumor cells as a surrogate for response to treatment and overall survival in metastatic breast cancer. Breast Cancer 2010;17:199-204.

151 Satelli A, Brownlee Z, Mitra A, Meng QH, Li $S$ : Circulating tumor cell enumeration using a combination of EPCAM and cell-surface vimentin based methods for monitoring breast cancer therapeutic response. Clin Chem 2015;61:259-266.

152 Mego M, Mani S, Lee B, Li C, Evans K, Cohen E, Gaol H, Jackson S, Giordano A, Hortobagyi G, Cristofanilli M, Lucci A, Reuben $\mathrm{J}$ : Expression of epithelial-mesenchymal transition-inducing transcription factors in primary breast cancer: the effect of neoadjuvant therapy. Int J Cancer 2012;130:808816
153 Zheng X, Carstens JL, Kim J, Scheible M, Kaye J, Sugimoto H, Wu CC, LeBleu VS, Kalluri R: Epithelial-to-mesenchymal transition is dispensable for metastasis but induces chemoresistance in pancreatic cancer. Nature 2015;527:525-530.

154 Khoo BL, Lee SC, Kumar P, Tan TZ, Warkiani ME, Ow SGW, Nandi S, Lim CT, Thiery JP: Short-term expansion of breast circulating cancer cells predicts response to anticancer therapy. Oncotarget 2015;6:1557815593.

155 Reijm EA, Sieuwerts AM, Smid M, Vries JBD, Mostert B, Onstenk W, Peeters D, Dirix LY, Seynaeve CM, Jager A, de Jongh FE, Hamberg P, van Galen A, Kraan J, Jansen MPHM, Gratama JW, Foekens JA, Martens JWM, Berns EMJJ, Sleijfer S: An 8-gene mRNA expression profile in circulating tumor cells predicts response to aromatase inhibitors in metastatic breast cancer patients. BMC Cancer 2016;16:123.

156 Bredemeier M, Edimiris P, Tewes M, Mach P, Aktas B, Schellbach D, Wagner J, Kimmig R, Kasimir-Bauer S: Establishment of a multimarker qPCR panel for the molecular characterization of circulating tumor cells in blood samples of metastatic breast cancer patients during the course of palliative treatment. Oncotarget 2016; 7:41677-41690.

157 Babayan A, Hannemann J, Spötter J, Müller V, Pantel K, Joosse SA: Heterogeneity of estrogen receptor expression in circulating tumor cells from metastatic breast cancer patients. PLoS One 2013;8:e75038.

158 Aktas B, Kasimir-Bauer S, Müller V, Janni W, Fehm T, Wallwiener D, Pantel K, Tewes M, Group DS: Comparison of the HER2, estrogen and progesterone receptor expression profile of primary tumor, metastases and circulating tumor cells in metastatic breast cancer patients. BMC Cancer 2016; 16:522.

159 Paoletti C, Larios JM, Muñiz MC, Aung K, Cannell EM, Darga EP, Kidwell KM, Thomas DG, Tokudome N, Brown ME, Connelly MC, Chianese DA, Schott AF, Henry NL, Rae JM, Hayes DF: Heterogeneous estrogen receptor expression in circulating tumor cells suggests diverse mechanisms of fulvestrant resistance. Mol Oncol 2016;10:10781085.

160 Bouris P, Skandalis SS, Piperigkou Z, Afratis N, Karamanou K, Aletras AJ, Moustakas A, Theocharis AD, Karamanos NK: Estrogen receptor alpha mediates epithelial to mesenchymal transition, expression of specific matrix effectors and functional properties of breast cancer cells. Matrix Biol 2015;43:4260.

161 Al Saleh S, Al Mulla F, Luqmani YA: Estrogen receptor silencing induces epithelial to mesenchymal transition in human breast cancer cells. PLoS One 2011;6:e20610.
162 Guan X, Ma F, Liu S, Wu S, Xiao R, Yuan L, Sun X, Yi Z, Yang H, Xu B: Analysis of the hormone receptor status of circulating tumor cell subpopulations based on epithelialmesenchymal transition: a proof-of-principle study on the heterogeneity of circulating tumor cells. Oncotarget 2016;7:6599366002 .

163 Wang Z, Zhang X, Shen P, Loggie BW, Chang Y, Deuel TF: A variant of estrogen receptor- $\alpha$, HER- $\alpha 36$ : transduction of estrogen- and antiestrogen-dependent membrane-initiated mitogenic signaling. Proc Natl Acad Sci USA 2006;103:9063-9068.

164 Chamard-Jovenin C, Jung AC, Chesnel A, Abecassis J, Flament S, Ledrappier S, Macabre C, Boukhobza T, Dumond H: From ERa66 to ERa36: a generic method for validating a prognosis marker of breast tumor progression. BMC Syst Biol 2015;9:28

165 Ingthorsson S, Andersen K, Hilmarsdottir B, Maelandsmo GM, Magnusson MK, Gudjonsson T: HER2 induced EMT and tumorigenicity in breast epithelial progenitor cells is inhibited by coexpression of EGFR. Oncogene 2016;35:4244-4255.

166 Smerage JB, Barlow WE, Hortobagyi GN, Winer EP, Leyland-Jones B, Srkalovic G, Tejwani S, Schott AF, O'Rourke MA, Lew DL, Doyle GV, Gralow JR, Livingston RB, Hayes DF: Circulating tumor cells and response to chemotherapy in metastatic breast cancer: SWOG S0500. J Clin Oncol 2014;32: 3483-3489.

167 Ignatiadis M, Rack B, Rothé F, Riethdorf S, Decraene C, Bonnefoi H, Dittrich C, Messina C, Beauvois M, Trapp E, Goulioti T, Tryfonidis K, Pantel K, Repollet M, Janni W, Piccart M, Sotiriou C, Litiere S, Pierga J-Y: Liquid biopsy-based clinical research in early breast cancer: the EORTC 90091-10093 Treat CTC trial. Eur J Cancer 2016;63:97104.

168 Georgoulias V, Bozionelou V, Agelaki S, Perraki M, Apostolaki S, Kallergi G, Kalbakis K, Xyrafas A, Mavroudis D: Trastuzumab decreases the incidence of clinical relapses in patients with early breast cancer presenting chemotherapy-resistant CK-19 mRNA-positive circulating tumor cells: results of a randomized phase II study. Ann Oncol 2012;23:1744-1750.

169 Agelaki S, Kalykaki A, Markomanolaki H, Papadaki MA, Kallergi G, Hatzidaki D, Kalbakis K, Mavroudis D, Georgoulias V: Efficacy of lapatinib in therapy-resistant HER2positive circulating tumor cells in metastatic breast cancer. PLoS One 2015; 10:e0123683.

170 Javaid S, Zhang J, Smolen GA, Yu M, Wittner BS, Singh A, Arora KS, Madden MW, Desai R, Zubrowski MJ, Schott BJ, Ting DT, Stott SL, Toner M, Maheswaran S, Shioda T, Ramaswamy S, Haber DA: MAPK7 regulates EMT features and modulates the generation of CTCs. Mol Cancer Res 2015;13:934-943. 
171 Yoshida T, Ozawa Y, Kimura T, Sato Y, Kuznetsov G, Xu S, Uesugi M, Agoulnik S, Taylor N, Funahashi Y, Matsui J: Eribulin mesilate suppresses experimental metastasis of breast cancer cells by reversing phenotype from epithelial-mesenchymal transition (EMT) to mesenchymal-epithelial transition (MET) states. Br J Cancer 2014;110:14971505.

172 Amirkhosravi A, Meyer T, Chang J, Amaya M, Siddiqui F, Desai H, Francis J: Tissue factor pathway inhibitor reduces experimental lung metastasis of B16 melanoma. Thromb Haemost 2002;87:930-936.

173 Wenzel J, Zeisig R, Fichtner I: Inhibition of metastasis in a murine $4 \mathrm{~T} 1$ breast cancer model by liposomes preventing tumor cellplatelet interactions. Clin Exp Metastasis 2010;27:25-34.

174 Borsig L, Wong R, Feramisco J, Nadeau DR, Varki NM, Varki A: Heparin and cancer revisited: Mechanistic connections involving platelets, $\mathrm{P}$-selectin, carcinoma mucins, and tumor metastasis. Proc Natl Acad Sci USA 2001;98:3352-3357.

175 Mohammad KS, Javelaud D, Fournier PGJ, Niewolna M, McKenna CR, Peng XH, Duong V, Dunn LK, Mauviel A, Guise TA: TGF- $\beta$-RI kinase inhibitor SD-208 reduces the development and progression of melanoma bone metastases. Cancer Res 2011;71: 175-184.

176 Park C, Min K, Son J, Park S, Nam J, Kim D, Sheen Y: An novel inhibitor of TGF-beta type I receptor, IN-1130, blocks breast cancer lung metastasis through inhibition of epithelial-mesenchymal transition. Cancer Lett 2014;351:72-80.
177 Rothwell PM, Wilson M, Price JF, Belch JFF, Meade TW, Mehta Z: Effect of daily aspirin on risk of cancer metastasis: a study of incident cancers during randomised controlled trials. Lancet 2012;379:1591-1601.

178 Lou X-L, Deng JUN, Deng H, Ting Y, Zhou LV, Liu Y-H, Hu J-P, Huang X-F, Qi X-Q: Aspirin inhibit platelet-induced epithelialto-mesenchymal transition of circulating tumor cells (review). Biomed Rep 2014;2:331334.

179 Li J, Ai Y, Wang L, Bu P, Sharkey CC, Wu Q, Wun B, Roy S, Shen X, King MR: Targeted drug delivery to circulating tumor cells via platelet membrane-functionalized particles. Biomaterials 2016;76:52-65.

180 De Luca F, Rotunno G, Salvianti F, Galardi F, Pestrin M, Gabellini S, Simi L, Mancini I, Vannucchi AM, Pazzagli M, Di Leo A, Pinzani P: Mutational analysis of single circulating tumor cells by next generation sequencing in metastatic breast cancer. Oncotarget 2016;7:26107-26119.

181 Pestrin M, Salvianti F, Galardi F, De Luca F, Turner N, Malorni L, Pazzagli M, Di Leo A, Pinzani P: Heterogeneity of PIK3CA mutational status at the single cell level in circulating tumor cells from metastatic breast cancer patients. Mol Oncol 2015;9:749-757.

182 Vishnoi M, Peddibhotla S, Yin W, Scamardo A, George GC, Hong DS, Marchetti D: The isolation and characterization of CTC subsets related to breast cancer dormancy. Sci Rep 2015;5:17533.

183 Fernandez SV, Bingham C, Fittipaldi P, Austin L, Palazzo J, Palmer G, Alpaugh K, Cristofanilli M: Tp53 mutations detected in circulating tumor cells present in the blood of metastatic triple negative breast cancer patients. Breast Cancer Res 2014;16:445.
184 Gorges TM, Kuske A, Röck K, Mauermann O, Müller V, Peine S, Verpoort K, Novosadova V, Kubista M, Riethdorf S, Pantel K: Accession of tumor heterogeneity by multiplex transcriptome profiling of single circulating tumor cells. Clin Chem 2016;62:1504-1515.

185 Giordano A, Gao H, Anfossi S, Cohen E, Mego M, Lee BN, Tin S, De Laurentiis M, Parker CA, Alvarez RH, Valero V, Ueno NT, De Placido S, Mani SA, Esteva FJ, Cristofanilli M, Reuben JM: Epithelial-mesenchymal transition and stem cell markers in patients with HER2-positive metastatic breast cancer. Mol Cancer Ther 2012;11:2526-2534.

186 Mego M, Cierna Z, Janega P, Karaba M, Minarik G, Benca J, Sedlácková T, Sieberova G, Gronesova P, Manasova D, Pindak D, Sufliarsky J, Danihel L, Reuben J, Mardiak J: Relationship between circulating tumor cells and epithelial to mesenchymal transition in early breast cancer. BMC Cancer 2015;15:1-9.

187 Wang H-Y, Ahn S, Kim S, Park S, Jung D, Park S, Han H, Sohn J, Kim S, Lee H: Detection of circulating tumor cell-specific markers in breast cancer patients using the quantitative rt-PCR assay. Int J Clin Oncol 2015; 20:878-890

188 Wu S, Liu S, Liu Z, Huang J, Pu X, Li J, Yang D, Deng H, Yang N, Xu J: Classification of circulating tumor cells by epithelial-mesenchymal transition markers. PLoS One 2015; 10:e123976.

189 Hensler M, Vančurová I, Becht E, Palata O, Strnad $\mathrm{P}$, Tesařová $\mathrm{P}$, Čabiňaková $\mathrm{M}$, Švec D, Kubista M, Bartůňková J, Špíšek R, Sojka L: Gene expression profiling of circulating tumor cells and peripheral blood mononuclear cells from breast cancer patients. Oncoimmunology 2016;5:e1102827.
Circulating Tumor Cell Research and Epithelial-Mesenchymal Transition
Pathobiology 2017;84:264-283 DOI: $10.1159 / 000477812$ 